\begin{tabular}{|c|c|}
\hline Title & An A naly sis of Global R\&D A ctivities of Japanese MNCs in the US From the Knowledge Based V iew \\
\hline Author(s) & Iwata, S.; Kurokawa, S.; Fujisue, K. \\
\hline Citation & $\begin{array}{l}\text { IEEE Transactions on Engineering Management, 53(3), 361-379 } \\
\text { https://doi.org/10.1109// EM.2006.877448 }\end{array}$ \\
\hline Issue Date & $2006-08$ \\
\hline Doc URL & http:/hdl.handle.net/2115/14618 \\
\hline Rights & $\begin{array}{l}\text { ○2006 IEEE. Personal use of this material is permitted. However, permission to reprint/republish this material for } \\
\text { advertising or promotional purposes or for creating new collective works for resale or redistribution to servers or lists, } \\
\text { or to reuse any copyrighted component of this work in other works must be obtained from the IEEE. IEEE, Engineering } \\
\text { Management, I IEEE Transactions on } \\
\text { V olume 53, Issue 3, A ug. } 2006 \text { Page(s):361-379 }\end{array}$ \\
\hline Type & article \\
\hline File Information & TEM 2006-53-3.pdf \\
\hline
\end{tabular}

Instructions for use 


\title{
An Analysis of Global R\&D Activities of Japanese MNCs in the US From the Knowledge-Based View
}

\author{
Satoshi Iwata, Sam Kurokawa, and Kenzo Fujisue
}

\begin{abstract}
We examined 79 Japanese MNCs' R\&D subsidiaries in the US from the knowledge-based view. We found: 1) subsidiaries' R\&D strategies encouraged some types of knowledge flows, but discouraged other types; 2) autonomous R\&D subsidiaries promoted knowledge flows from local environments to the subsidiary; 3) process-oriented incentives promoted technical knowledge flows between a subsidiary and its headquarters; 4) knowledge flows and R\&D strategies contributed to a subsidiary's knowledge accumulation; 5) organizational factors such as autonomy and process-oriented incentives contributed more to a subsidiary's overall performance than the subsidiary's $R \& D$ strategies did.
\end{abstract}

Index Terms-International subsidiaries, knowledge-based view, R\&D management.

\section{INTRODUCTION}

$\mathbf{E}$ XTERNAL technological markets continue to become more global and efficient, primarily due to the advancements in IT-based communication and database methods. For example, web-based knowledge sharing sites, such as "Innocentive," started by Eli Lilly in 2001, have become popular outsourcing methods for technological problem-solving among multi-national corporations (MNCs) [93].

External markets, however, remain relatively ineffective mechanisms for knowledge sharing and transfer because: 1 ) the specialized knowledge of firms tends to be tacit and thereby difficult to transfer; 2) market-based transfers of knowledge are often associated with negative externalities such as involuntary expropriation and the risk of creating a new competitor [122].

Thus, in the last decade, MNCs seem to be globalizing their R\&D activities by using internal governance mechanisms [36], [52], [64]. For example, a study by the National Science Foundation (NSF) shows that over the last ten years, U.S. companies' investment in overseas R\&D has increased three times faster than company funded domestic R\&D-10.1\% versus $3.4 \%$. Overseas R\&D now accounts for 12 percent of the U.S. industry's domestic R\&D expenditures [103].

However, there are only a few studies that shed light on such global R\&D activities by MNCs, especially by Japanese MNCs.

Manuscript received August 3, 2004; revised May 8, 2005; June 23, 2005, and September 20, 2005. Review of this manuscript was arranged by Editor, R. Keller.

S. Iwata is with the Graduate School of Economics \& Business Administration, Hokkaido University, Sapporo 060-0809, Japan (e-mail: iwata@econ. hokudai.ac.jp).

S. Kurokawa is with the Department of Management, LeBow College of Business, Drexel University, Philadelphia, PA 19104 USA (e-mail: sk92@drexel. edu).

K. Fujisue is with the Department of Engineering, Waseda University, Tokyo 69-0051, Japan (e-mail: fujisue@ aol.com).

Digital Object Identifier 10.1109/TEM.2006.877448
Furthermore, there are few theoretical and empirical studies that can answer the question: "How should global $R \& D$ activities be organized efficiently?." In an effort to fill this gap in our understanding, the current study investigates global knowledge flows in Japanese R\&D subsidiaries in the US, from the knowledge-based view of MNCs [36], [52].

We believe that this research sheds light on a general aspect of R\&D globalization, because: 1) the US offers the most attractive "host" location for global R\&D subsidiaries [110]; 2) many empirical studies have indicated that a majority of R\&D facilities in the US owned by foreign firms are Japanese [29], [39], [117]; 3) a majority of Japanese MNCs' overseas R\&D facilities are reported to be located in the US [70], [72].

This paper attempts to answer the following four research questions: 1) what factors will determine knowledge flows among R\&D subsidiaries, headquarters (HQ), and other R\&D subsidiaries?; 2) what factors will determine knowledge accumulations of R\&D subsidiaries?; 3) what factors will determine performance of R\&D subsidiaries?; 4) how should R\&D subsidiaries manage knowledge flows for higher performance?

In order to answer these questions, this paper includes the following four major sections. First, the paper discusses global $R \& D$ activities by surveying the relevant literature. Second, it constructs several hypotheses based on the knowledge-based view. Third, it tests these hypotheses by using survey data from 79 Japanese R\&D subsidiaries in the US. Finally, it concludes with managerial implications and suggestions for future research.

\section{THEORETICAL FRAMEWORK AND HyPOTHESES}

\section{A. Knowledge-Based View of MNCs}

Hymer [64] originally argued that MNCs' raison d'être lies in the ability to internally exploit knowledge more efficiently than would be possible through external market mechanisms. Such a perspective emphasizes that globally dispersed R\&D operations provide MNCs with competitive advantages not available in single-country centralized R\&D operations [20], [37], [111], and that such a competitive advantage is based on how efficiently MNCs share knowledge across HQs and R\&D subsidiaries [36], [52]. Such a view can be called "the knowledgebased view (KBV) of MNCs."

In spite of the criticality of "knowledge shares and transfers within MNCs"-labeled as "knowledge flows" henceforth—we have a limited understanding of how to efficiently manage such knowledge flows. This is because only a limited number of studies have empirically investigated the determinants of knowledge flows. 
TABLE I

EMPIRICAL STUDIES ON KNOWLEDGE FLOWS IN MNCs

\begin{tabular}{|c|c|c|c|c|c|}
\hline & Unit of Analysis & $\begin{array}{l}\text { Country origin } \\
\text { of MNCs }\end{array}$ & $\begin{array}{l}\text { Knowledge Flow } \\
\text { Measurement }\end{array}$ & $\begin{array}{l}\text { Performance } \\
\text { Measurement }\end{array}$ & $\begin{array}{l}\text { Major } \\
\text { Findings }\end{array}$ \\
\hline Nobel and Birkinshaw (1998) & $110 \mathrm{R} \& \mathrm{D}$ subs in $15 \mathrm{MNCs}$ & Sweden & $\begin{array}{l}\text { Actual frequency of } \\
\text { communications in } \\
\text { both face-to-face and } \\
\text { other methods }\end{array}$ & N/A & Communication methods vary depending on types of R\&D subs. \\
\hline Gupta and Govindarajan (2000) & 374 general subs in $75 \mathrm{MNCs}$ & US, Europe, Japan & 6 Likert-type questions & N/A & $\begin{array}{l}\text { Knowledge flows are associated with sub's knowledge stock, } \\
\text { absorptive capacity, motivational disposition and the richness of } \\
\text { transmission channels. }\end{array}$ \\
\hline Subramaniam and Venkatraman (2001) & $\begin{array}{l}90 \text { new product development } \\
\text { projects in } 52 \mathrm{MNCs}\end{array}$ & $\begin{array}{l}\text { US, Europe, Japan, and } \\
\text { Korea }\end{array}$ & 3 Likert-type questions & N/A & $\begin{array}{l}\text { Global product development capabilities of MNCs depend upon } \\
\text { their ability to transfer and deploy tacit knowledge concerning } \\
\text { overseas markets. }\end{array}$ \\
\hline Hakanson and Nobel (2001) & $120 \mathrm{R} \& \mathrm{D}$ subs in $18 \mathrm{MNCs}$ & Sweden & $\begin{array}{l}\text { Actual technology } \\
\text { transfer from subs to } \\
\text { HQs (a dummy) }\end{array}$ & N/A & The higher integration, the more tech. flow from subs to HQs. \\
\hline Birkinshaw et al (2002) & $110 \mathrm{R} \& \mathrm{D}$ subs in $15 \mathrm{MNCs}$ & Sweden & $\begin{array}{l}\text { Frequency of } \\
\text { technological know- } \\
\text { how transfer }\end{array}$ & N/A & $\begin{array}{l}\text { Two dimensions of knowledge—observability and system } \\
\text { embeddedness-influence knowledge flows. }\end{array}$ \\
\hline Almeida et al (2002) & $\begin{array}{l}21 \text { MNCs in the } \\
\text { semiconductor industry }\end{array}$ & $\begin{array}{l}\text { US, Japan, Taiwan, } \\
\text { Korea, Singapore, Italy, } \\
\text { France, Germany, } \\
\text { Netherlands, UK }\end{array}$ & Patent citations & N/A & $\begin{array}{l}\text { The superiority of MNCs stems from their ability to use multiple } \\
\text { mechanisms of knowledge transfer flexibly and simultaneously. }\end{array}$ \\
\hline Cummings and Teng (2003) & $69 \mathrm{HQs}$ in US & US & $\begin{array}{l}22 \text { Likert-type } \\
\text { questions on } \\
\text { knowledge flow } \\
\text { success }\end{array}$ & $\begin{array}{l}\text { The same as } \\
\text { knowledge flow } \\
\text { measures }\end{array}$ & $\begin{array}{l}\text { knowledge transfer success was associated with the extent of } \\
\text { interactions and articulation processes. }\end{array}$ \\
\hline Foss and Pedersen (2003) & $\begin{array}{l}2,107 \text { general subs in Austria, } \\
\text { Denmark, Finland, Germany, } \\
\text { Norway, Sweden and UK }\end{array}$ & Not Specified & $\begin{array}{l}6 \text { Likert-type questions } \\
\text { on knowledge flow }\end{array}$ & N/A & $\begin{array}{l}\text { MNC management can influence knowledge flows through choices } \\
\text { regarding control, motivation and context. }\end{array}$ \\
\hline Minbaeva et al (2003) & $\begin{array}{l}169 \text { general subs in US, } \\
\text { Russia, China }\end{array}$ & Not specified & 2 Likert-type questions & N/A & Interaction of ability and motivation facilitates knowledge flows. \\
\hline
\end{tabular}

Note: Subs-Subsidiaries, HQs-Headquarters, General Sub-Subsidiaries for marketing, manufacturing and/or R\&D

The reason for such a paucity of studies could stem from difficulties in accessing actual knowledge flows in MNCs. However, we identified the following nine "exceptional" studies, based on the following two criteria: 1) studies must be based on KBV of MNCs; 2) studies must measure actual knowledge flows in MNCs. We will briefly review these nine studies below-Table I summarizes these studies. ${ }^{1}$

By studying $110 \mathrm{R} \& \mathrm{D}$ subsidiaries in 15 Swedish MNCs, Nobel and Birkinshaw [98] argue that effective communication methods (e.g., face-to-face) and directions (e.g., with other global R\&D subsidiaries) vary depending on specific types of R\&D subsidiaries (e.g., global creator). In their extensive study of 374 subsidiaries in 75 MNCs in US, Europe and Japan, Gupta and Govindarajan [52] found that subsidiaries' knowledge stock, absorptive capacity, motivational disposition and the richness of transmission channels promote knowledge flows.

By examining 91 new product development projects in 52 MNCs in US, Europe, Japan, and Korea, Subramaniam and Venkatraman [119] found that MNCs' ability to transfer and deploy tacit knowledge concerning overseas markets leads to successful global product developments. Hakanson and Nobel [54] studied 120 R\&D subsidiaries in 18 Swedish MNCs, and found that a higher level of intra-MNCs integration promotes technological knowledge flows from subsidiaries to HQs.

\footnotetext{
${ }^{1}$ Egelhoff [38] examined knowledge flows between headquarters and subsidiaries of MNCs by focusing on control mechanisms. Rosenzweig and Nohria [115] also studied HR practices in MNCs and found that knowledge flows affect subsidiaries' HR practices. However, we excluded these studies from our review, because these studies were not based on KBV of MNCs.
}

By examining $110 \mathrm{R} \& \mathrm{D}$ subsidiaries in 15 Swedish MNCs, Birkinshaw, et al. [15] found that two dimensions of knowledge, observability - the extent to which it is easy to understand the activity by examining different aspects of the process or final product - and embeddedness - the extent to which knowledge is a function of the social and physical system in which it exits-stimulate knowledge flows. Almeida, et al. [6] also examined $21 \mathrm{MNCs}$ in the semiconductor industry in ten countries, and argued that the superiority of MNCs stems from their ability to use multiple mechanisms of knowledge flows flexibly and simultaneously.

Furthermore, by examining 69 headquarters in American MNCs, Cummings and Teng [28] found that knowledge flow success was associated with 1) R\&D units' understanding where the desired knowledge resides, 2) the extent to which the parties share similar knowledge bases, 3) the extent of interactions between the source and the recipient, and 4) articulation processes through which the source's knowledge is made accessible to the recipient.

By examining more than two thousand subsidiaries in seven countries, Foss and Pedersen [40] argue that MNC management can influence knowledge flows through choices regarding control, motivation and context. Finally, Minbaeva, et al. [91] examined 169 subsidiaries in US, Russia, and China, and found that knowledge flows tended to be promoted by investments in knowledge receivers' ability and motivation through the extensive use of training, performance appraisal, performance-based compensation and internal communication.

There are several tendencies in these empirical studies on knowledge flows in MNCs. First, most of these studies investi- 
gated general subsidiaries such as manufacturing or marketing subsidiaries within MNCs. Only two studies-i.e., Hakanson and Nobel [54] and Birkinshaw, et al. [15]—examined knowledge flows specifically in R\&D subsidiaries within MNCs.

Second, although Subramaniam and Venkatraman [119], Almeida, et al. [6], and Gupta and Govindarajan [52] examined Japanese MNCs as a part of their studies, there is no empirical study on knowledge flows, specifically focusing on Japanese MNCs and their R\&D subsidiaries. Although there are some survey-based studies on recent global R\&D activities in Japanese MNCs, these studies have primarily focused on "external factors," such as when, how, and why Japanese MNCs globalized their R\&D activities. ${ }^{2}$

Third, with the exception of Subramaniam and Venkatraman [119], and Gupta and Govindarajan [52], these studies measured technology-related knowledge flows, but did not measure market-related knowledge flows. We argue that both technology and market-related knowledge flows are important in order to examine the validity of KBV of MNCs, as will be elaborated in the following section.

Fourth, most of these studies measured either knowledge in-flows from HQs to subsidiaries-e.g., [28], [91]—or knowledge out-flows from subsidiaries to HQs-e.g., [15], [54]. Following Gupta and Govindarajan [52], we argue that both knowledge in-flows and out-flows should be measured in order to test the validity of KBV of MNCs.

Fifth, missions and functions of a variety of R\&D subsidiaries have been theoretically discussed in many studies, and numerous typologies have been proposed-e.g., home-base-exploiting sites and home-base-augmenting sites [77], [109]; local adapters, international adapters, and international creators [98]. However, there are few empirical studies from the KBV that actually measured such typologies, except for Nobel and Birkinshaw [98].

Finally, most of these empirical studies either 1) used knowledge flows as performance indicators or 2) assumed that a high level of knowledge flows leads to high performance. We argue that knowledge flows are cost-involving activities-i.e., there must be an optimal level of knowledge flows. Our arguments will be elaborated further in the following section.

\section{B. Knowledge Flow/Accumulation and Performance}

The KBV of MNCs seems to assume: the higher the level of knowledge flows, the higher the MNCs' (and/or subsidiaries') performance, by extending information processing perspective

${ }^{2}$ For example, by studying 137 Japanese MNCs, Iwasa and Odagiri [68] found that HQs' R\&D expenditure, the US subs' R\&D expenditures, the presence of R\&D in Europe, and the firm's experience in the US, positively contributed to inventions (measured by patents) at home and in the US among firms, whose $R \& D$ subs mainly aim to research. On the other hand, such positive contributions were not observed in firms, whose R\&D subs mainly aim to support local manufacturing and sales activities. Similar survey-based studies include Serapio and Dalton [108], Odagiri and Yasuda [105], Florida and Kenney [39], and Odagiri and Goto [104]. An exception is Asakawa [10], [11]. By surveying 44 Japanese MNCs and $66 \mathrm{R} \& \mathrm{D}$ subs, Asakawa identified the evolving nature of headquarters-subsidiary relations during the whole process of R\&D internationalization of Japanese MNCs. He found that the tension between HQs and R\&D subs was more salient in information-sharing issues than in autonomy-control issues, and that R\&D subs were more dissatisfied with the current level of information sharing and granted autonomy than HQs were.
[38], [41]. However, we cast serious doubt on its assumption for the following three reasons. First, the assumption disregards the intervening role of knowledge accumulation into the relationship between knowledge flows and performance.

Havelock [58] and Machlup and Mansfield [88] argue that "information" is a flow of messages, whereas "knowledge" is a stock. By extending their arguments, we argue that "knowledge accumulation" is a stocked assets, and that knowledge flows are activities, thus involving costs. Here, "knowledge accumulation" can be defined as "stored knowledge in forms of documents, papers, patents, copyrights or new products/services" [49], [90]. Furthermore, we argue that both market- and technology-related knowledge flows are critically important for effective knowledge accumulation.

The importance of market- and technology-related knowledge flows has been extensively examined in the new product development (NPD) literature-e.g., Tatikonda and Rosenthal [121], Sicotte and Langley [118], Ottum and Moore [107], and Kahn [75]. The NPD literature has been suggesting that technical knowledge flows either from in-house R\&D efforts or from external sources-e.g., collaborative R\&D projects or licensing - and market-related knowledge flows from customers should be efficiently converted into "accumulated knowledge."

By extending the above arguments, Nonaka and Toyama [101], [102] argue that a firm can create new knowledge in "dialectic" manners by combining the externally acquired knowledge-mainly consisting of market-related knowledge-with the existing knowledge accumulated within the firm boundaries-mainly consisting of technology-related knowledge - only through the dynamic context. ${ }^{3}$

March [89] and Dierickx and Cool [34] argue that the accumulation of strategic stocks (e.g., firm knowledge) is achieved over time through a constant flow of knowledge, resources and capabilities (e.g., effective problem-solving). Although all the knowledge flows may not necessarily lead to knowledge accumulation, we argue that there is a positive relationship between knowledge flows and knowledge accumulation.

Second, the assumption that a high level of knowledge flows leads to a high level of MNCs' performance tends to disregard the qualitative aspects of knowledge flows and knowledge accumulation processes. For example, market-related knowledge flows concerning a specific customer's hidden needs could have

\footnotetext{
${ }^{3}$ Nonaka and Toyama [101], [102] also argue that "Ba"-roughly meaning "place or community" in English-offers such a dynamic context which links visions, practices, and dialogues. We argue that the "Ba" proposed by Nonaka and Toyama [101], [102] is very similar to "communities-of-practices," proposed by Lave and Wenger [83]. The concept of "Ba" was originally proposed by Japanese philosopher Kitaro Nishida [93]. According to Nonaka and Konno [97], $\mathrm{Ba}$ is a context, which harbors meaning, and can be considered as a shared space that serves as a foundation for knowledge creation. This space can be physical (e.g., office, dispersed business space), virtual (e.g., e-mail, teleconference), mental (e.g., shared experiences, ideas, ideals) or any combination of them. Itami [64] suggests that $B a$ consists of five valuables-i.e., 1) agenda, 2) codes of sense, 3) information carriers, 4) motivation for co-partnership, and 4) membership. Agenda is a topic for discussion. Codes of sense are interpretation frameworks of information for participants in $\mathrm{Ba}$. Information carriers are medias such as language or document, which can be communicated among participants. Itami argues that $\mathrm{Ba}$ is a frame under which agenda, codes of sense, and information carriers are shared by those who participate in. Hara [54] defines "communities-of-practice" as informal networks that support professional practitioners to develop a shared meaning and engage in knowledge building among the members," and suggests that learning and innovation cannot be separated from social interaction and practical experience, both of which are vital processes for tacit knowledge creation.
} 
various meanings and be interpreted differently according to MNCs' or subsidiaries' accumulated knowledge. ${ }^{4}$

Kagono [73] argues that "new meanings" will be created when knowledge flows enter into an organization's accumulated knowledge, and that new meanings lead to new technologies, products or services. Such an argument is also made in interpretive sociology [116], symbolic interactionism [16], the sociology of knowledge [14], and cognitive social psychology [131].

Schutz [116] argues that interpretation may be one of the most important functions organizations perform. We argue that such interpretation can shape both knowledge flows and accumulations, and that both knowledge flows and accumulations shape the interpretation, as well. Such a unique organizational capability can be called "interpretative capacity."

We assume that the essential nature of knowledge accumulations is in their interpretative functions rather than their activity-related functions such as their maintenance or retrieval. Thus, although knowledge accumulations may involve costs associated with their maintenance or retrieval activities, we assume that these costs are negligible. ${ }^{5}$

The literature on the resource-based view of the firms (RBV) has argued that accumulated resources (such as knowledge) could have negative effects on performance by proposing "core rigidity" [84] or "competence trap" [86]. The literature on knowledge management has also suggested such negative aspects of knowledge accumulation by proposing "knowledge depreciation" [30], or "organizational forgetting" [13]. For example, Darr et al. [30] argue that accumulated knowledge becomes obsolete. Benkard [13] and Argote and Epple [8] also argue that firms tend to accumulate knowledge that is not related to their core capabilities.

However, most studies on knowledge depreciation or organizational forgetting were conducted in large-scale traditional operating situations - e.g., ship building during the World War [8], [124], wide-body airframe manufacturing [13], and pizza franchising [30]. We argue that such negative aspects of knowledge accumulation are negligible in this study, because overseas R\&D subsidiaries are "genuine knowledge generating organizations," and are generally small in size and new in their establishments.

Finally, the assumption that a high level of knowledge flows leads to a high level of MNCs' performance disregards knowledge accumulation's positive impact on performance. The accumulation of knowledge and its impact on innovative capabilities

\footnotetext{
${ }^{4}$ An example, used by many Japanese management educators, is a case of two identical Japanese shoes manufactures. One manufacturer dispatched a marketing staff member to Africa in the 50s to examine the market demand for shoes in Africa. After investigating the market, the member reported to the manufacture that there was no demand for shoes, because no one was wearing shoes at that time. Another shoe manufacturer also dispatched a marketing staff member to Africa to examine the market demand for shoes in Africa. After investigating the market, the member reported to the manufacture that there was a huge demand for shoes, because no one was wearing shoes! The latter manufacturer sold successfully many shoes in Africa.

${ }^{5}$ Crossan et al. [27] argued that organizational learning generally involves two stages: 1) exploration - assimilating new learning; 2) exploitation-using what has been learned. We argue that our "knowledge flows" are close to exploration, while our "knowledge accumulations" are close to exploitation. This is because: 1) knowledge flows are activities before using knowledge, as exploration is activity before using knowledge; 2) accumulated knowledge should be used, as exploitation is using knowledge; 3) knowledge flows lead to knowledge accumulations, as exploration leads to exploitation.
}

has received increasing attention from scholars of strategic management [62].

For example, the concept of "knowledge integration" [48], [65] emphasizes the ability to integrate different types of knowledge to develop new innovation-enhancing capabilities. Theories of "dynamic capabilities" [123] emphasize the role of knowledge as a source of innovation and competitive advantage.

Studies on social networks and inter-organizational relationships have also argued that knowledge flows among firms are essential to the innovation process (e.g., [87] and [114]). Furthermore, Helfat [61] found that during periods of environmental instability, firms with greater volumes of accumulated knowledge undertook greater amounts of R\&D. Yli-Renko et al. also [134] found a significant positive relationship between knowledge accumulation and new product development.

We argue that accumulated knowledge leads to informed, efficient and timely decision-making or problem-solving, thus achieving high performance. Several empirical studies support our argument. For example, Lane et al. [82] found that knowledge acquired from alliance partners contributed significantly to alliance performance in their study on alliance. Furthermore, Moenaert, et al. [92] found that the knowledge accumulated by project teams tends to have a higher association with project performance than does the level of knowledge flows in their study on NPD.

In summary, we argue: 1) it is not "knowledge flow" but "knowledge accumulation" that contributes to the performance of MNCs and their subsidiaries; 2) "new meanings" will be created by uniquely associating knowledge flows with accumulated knowledge of MNCs or their subsidiaries; 3) both market and technology-related knowledge flows are needed for the new meanings to have values or competitive advantages-i.e., valuable, rare, inimitable and non-substitutable [130].

\section{Factors Affecting Knowledge Flows}

Strategic Factors: In spite of the various typologies proposed on foreign R\&D subsidiaries, many studies are accepting that objectives or missions of foreign $\mathrm{R} \& \mathrm{D}$ subsidiaries are classified into two categories: 1) home-base-augmenting sites; 2) home-base-exploiting sites [25], [98], [109]. Home-base-augmenting sites can be defined as "sites established to enhance MNCs' core capabilities by tapping technological knowledge from local environments-i.e., local universities, local governments, suppliers, and competitors [77]. Nobel and Birkinshaw [98] and Chiesa [25] argue that home-base-augmenting sites tend to become a "center of excellence," by aiming at the basic end of the R\&D spectrum — consisting of basic research, applied research and development research [4] - thus making the subsidiary a center of technical knowledge flows.

On the other hand, home-base-exploiting sites can be defined as "sites established to support foreign manufacturing facilities or to adapt products to the foreign market [77]. Papanastassiou and Pearce [108] argue that home-base-exploiting sites tend to develop products/services tailored to local markets' needs, thus emphasizing market-related knowledge flows. 
Accordingly, we expect that home-base-augmenting sites require high levels of technology-related knowledge flows, while home-base-exploiting sites require high levels of market-related knowledge flows. Thus, we propose the following two hypotheses.

Hypothesis 1: Home-base-augmenting R\&D subsidiaries are likely to promote technology-related knowledge flows among the subsidiary, its parent company, other subsidiaries and its local environment.

Hypothesis 2: Home-base-exploiting R\&D subsidiaries are likely to promote market-related knowledge flows among the subsidiary, its parent company, other subsidiaries and its local environment.

Organizational Factors: The literature on knowledge management has reported difficulties in encouraging knowledge sharing among employees-e.g., Garvin and March [42]. We argue that "Ba" or "communities-of-practices" emphasize democratic or egalitarian aspects of knowledge sharing processes, which are necessary for generating new meanings and innovations within MNCs, by mitigating "prisoner's dilemma" situations [129]. Brown and Duguid [21], and Zaltman and Duncan [136] also support a similar argument. ${ }^{6}$

Many studies on organizational communications have suggested that trustful environments encourage knowledge flows among various units. For example, Bresman et al. [19] and Argote [7] argue that quick and effective sharing of knowledge across units can be significantly facilitated, when units share visions and beliefs. Recent research on social capital has also suggested that shared vision and trust strongly influence inter-unit knowledge flows [94], [127].

Researchers on MNCs have argued that "autonomous subsidiaries"-i.e., with decentralized decision-making practices and localized employees - and "incentive practices" are two main factors that are related to such trustful environments-e.g., Gupta and Govindarajan [52] and Zander and Kogut [137]. ${ }^{7}$

We argue that autonomous subsidiaries tend to engage in more active knowledge flows from local environments-e.g., local universities or local suppliers-by building a local image for the subsidiary. Bartlett and Ghoshal [12], and Aghion and Tirole [1] agree with our argument in that autonomous subsidiaries are likely to contribute to new technologies or products by active knowledge flows.

However, prior studies have also suggested that there is a danger that autonomous subsidiaries in MNCs run by local managers tend to develop into their own little fiefdoms, thus inhibiting knowledge flows between headquarters and subsidiaries [43], [46]. According to the above arguments, we propose the following two hypotheses.

\footnotetext{
${ }^{6}$ Such a dilemma seems to also stem from the "public good" nature of information-i.e., the same information can be used simultaneously without additional costs to others [80].

${ }^{7}$ In the study of MNCs, "centralization-decentralization or localization" has been fundamental dimensions of organization designs [38]. "Centralization and decentralization" are concerned with decision-makings, while "localization" is concerned with people [2]. Thus, "autonomous" subsidiary has decentralized decision-making practices and more localized employees.
}

Hypothesis 3: The greater autonomy of an R\&D subsidiary, the higher knowledge flows from its local environments to the subsidiary. ${ }^{8}$

Hypothesis 4: The greater autonomy of an $R \& D$ subsidiary, the lower knowledge flows between the subsidiary and its parent company.

Another organizational factor affecting knowledge flows is related to "incentives." Lane and Lubatkin [81] argue that incentive practices generally have positive associations with a firm's inter-organizational learning. Brelade and Harman [18] and Davenport et al. [32] argue that a firm should emphasize both extrinsic rewards (e.g., bonuses) and intrinsic rewards (e.g., interesting or challenging projects) in order to encourage knowledge flows among employees. This argument seems valid, particularly for R\&D personnel who tend to emphasize intrinsic rather than extrinsic rewards [4].

Studies on knowledge management have also reported that process-oriented incentives (i.e., based on leadership, teamwork, or commitment) may encourage knowledge sharing among employees, while outcome-based incentives (e.g., merit-based bonuses) may discourage knowledge sharing [53], [55]. The reason for this could be that knowledge is intimately connected with people's egos.

Furthermore, Burgelman [22], Ghemawat et al. [45], and Gupta and Govindarajan [51] argue that incentives for R\&D personnel should generally be flexible and loosely coupled to returns of $R \& D$, particularly in basic research-related activities, where the returns of $R \& D$ activities are not certain, and often times, highly risky [85].

Accordingly, we argue that R\&D subsidiaries' incentives should be linked with long-term and process- (or behavior-) oriented measurements (e.g., leadership, teamwork, or commitment) rather than short-term and outcome-oriented measurements (i.e., bonuses based on number of patents or papers). Thus, we propose the following hypothesis.

Hypothesis 5: The more process-oriented incentive practices an $R \& D$ subsidiary employs, the higher knowledge flows between the subsidiary and its parent company.

\section{Knowledge Accumulation and Performance}

Evaluating the performance of an R\&D subsidiary simply by financial measures such as ROI is not appropriate, because: 1) the result of $R \& D$ activities (i.e., knowledge) is not directly measurable, especially when tacit knowledge is involved [9]; 2) specific knowledge created in a subsidiary may have long-term pervasive impacts on HQs or other subsidiaries, occasionally without additional costs [45], [66]; 3) subsidiaries may specialize in different technological areas, and have different strategic priorities, thus requiring performance data to be adjusted for each subsidiary [50]. ${ }^{9}$

\footnotetext{
${ }^{8}$ By following Kuemmerle [78], we excluded knowledge flows from a subsidiary to local environments in our analyses, because: 1) such flows have been studied as "spillovers," mainly form a public policy perspective; 2 ) it is usually difficult to specify local partners for such knowledge flows.

${ }^{9}$ For example, our interview with a director of an Japanese R\&D subsidiary in the US emphasized the importance of "citation-index" as a performance measure of the subsidiary.
} 
Thus, most of the empirical studies from the KBV of MNCs either: 1) used knowledge flows as performance indicators of HQs and/or subsidiaries; or 2) assumed that a high level of knowledge flows leads to high performance of HQs and/or subsidiaries, as discussed. However, we argue that knowledge flows are cost-involving activities-i.e., there must be an optimal level of knowledge flow. We also argue that knowledge flows lead to knowledge accumulations, and that knowledge accumulations lead to performance.

Recent studies on the relationship between information flows and performance in a NPD context support our argument. These studies found: 1) information flows had a positive effect on NPD performance under a specific condition-e.g., when levels of ambiguity are high [118]; 2) information which was exchanged and "used" had a positive effect on NPD performance [107]; 3 ) accumulated knowledge functions as an important "bridge" variable between information flows and NPD performance [79]; 4) accumulated knowledge lead to NPD performance, through informed, efficient and timely decisions [79].

Accordingly, we argue: it is not knowledge flows, but the knowledge that is actually accumulated and used which contributes to performance. Thus, we propose the following two hypotheses.

Hypothesis 6: The higher knowledge flows among an R\&D subsidiary, its parent company, other R\&D subsidiaries, and its local environments, the higher level of knowledge the subsidiary tends to accumulate.

\section{Hypothesis 7: The higher level of knowledge an R\&D subsidiary accumulates, the higher the subsidiary's performance.}

\section{Methodology}

\section{A. Sample and Data Collection}

In this study, we examine Japanese MNCs' R\&D subsidiaries in the US. There are some case studies that shed light on Japanese MNCs' global R\&D activities. These studies revealed the following characteristics of Japanese MNCs, compared with American and European counterparts: 1) established more recently smaller-scaled R\&D subsidiaries [78]; 2) tend to co-locate with their manufacturing/marketing facilities [133], [135]; 3) tend to maintain stronger headquarter control over their R\&D subsidiaries by sending expatriates [12]; 4) tend to give priority to development and design for manufacturability, and the associated speed of new product introduction [133]; 5) are developing international network of basic research [59].

However, there are no empirical studies on Japanese R\&D subsidiaries in the US from the KBV, as discussed. Thus, the current study fills the gap among the previous studies on Japanese MNCs' R\&D activities abroad. Furthermore, we believe that this research sheds light on a general aspect of R\&D globalization, because of the following three reasons regarding the population.

First, the US offers the most attractive "host" location for global R\&D subsidiaries of MNCs. For example, Pearce and Papanastassiou [110] found that 530 global R\&D laboratories owned by MNCs originated from a variety of countries, and that $20 \%$ of them are located in the US, followed by UK (11.5\%), and Japan (9.4\%).
Second, many empirical studies have indicated that a majority of R\&D facilities in the US owned by foreign firms are Japanese. For example, Florida and Kenney [39] found that there were 174 R\&D facilities in the US owned by foreign companies, and that 44.3 percent of them ( 77 facilities) were owned by Japanese MNCs.

Dalton et al. [29] also found that there were 715 R\&D facilities in the US owned by foreign companies, and that $35 \%$ of them ( 250 facilities) were owned by Japanese MNCs, followed by German (15\%) and Korean (14\%) MNCs. Serapio and Dalton [117] also found that among the 25 largest R\&D facilities in the United States, nine were Japanese.

Third, a majority of Japanese MNCs' overseas R\&D facilities are reported to be located in the US. For example, Iwata [70] reported that slightly more than $50 \%$ of all Japanese MNCs' overseas R\&D facilities are located in the US, followed by European and Asian countries. Furthermore, it is reported that some Japanese MNCs, especially those in the pharmaceutical industry, are increasing their $R \& D$ investments mainly to the US, in spite of the recent overall economic downturn [72]. Accordingly, we believe that Japanese R\&D subsidiaries in the US represent (at least, quantitatively) the largest population-i.e., roughly $8 \%$ of the total number of MNCs' R\&D subsidiaries in the world. ${ }^{10}$

We collected data by surveying top managers (CEOs or presidents) of Japanese R\&D subsidiaries. We supplemented this information with publicly available data. Because these subsidiaries were rather small in size-i.e., the average number of R\&D personnel is 51-top management is assumed to have a thorough understanding of their subsidiaries. Therefore, the problem of "single respondent" bias was mitigated (although not perfectly resolved).

After developing the survey instrument in both English and Japanese, we asked seven managers of Japanese MNCs who were in charge of global R\&D management to provide comments on our instrument, particularly on our definition of knowledge flows. Based on these comments, we revised some of the wording of the questions.

The Toyo Keizai's directory on Japanese MNCs (Kaigai Shinshutsu Kigyou Souran) [125] identified 530 Japanese MNCs: 1) who were reported to conduct $R \& D$ activities in the US; 2) whose parent companies' equity investments were higher than 50\%. The directory identified not only independent $R \& D$ facilities, but also $R \& D$ activities conducted within manufacturing facilities.

By collaborating with the Japanese Ministry of Economy, Trade and Industry (METI), we mailed surveys to the top management of these subsidiaries. We received 85 responses-a response rate of 16 percent. However, we found that about onehalf (42 companies) of the 85 respondents were either "planning" R\&D activities, or not actually conducting any R\&D activities. Thus, we mailed a second-wave of surveys to those MNCs that did not respond to our initial survey. We received 80 responses - a response rate of 15.4 percent. Again, we found that about one-half ( 38 companies) of the 80 respondents were

${ }^{10} 20 \% \times(44.3 \%+35 \%) / 2=7.97 \% 20 \%$ is from Pearce and Papanastassiou [109]; 44.3\% is Florida and Kenney [39]; 35\% is from Dalton, et al. [29]. 
either planning R\&D activities or not actually conducting $R \& D$ activities.

Accordingly, approximately half of the Japanese MNCs listed in the Toyo Keizai's directory were not actually conducting significant $R \& D$ activities. This finding is consistent with Serapio and Dalton's [117] finding-i.e., they found 249 Japanese R\&D subsidiaries in the US. Six responses had significantly missing data and could not be used. Thus, the current study is based on the remaining 79 respondents (40 from the first-wave and 39 from the second-wave), representing roughly one-third of the population-i.e., 79 from 249 subsidiaries by Serapio and Dalton [117]. ${ }^{11}$

We checked non-respondent bias by observing the size of the subsidiaries and their parent companies that did not respond to our survey. We found that non-responding subsidiaries and their parent companies were not statistically different in size from those who did respond. We also checked those who responded to our first-wave survey with those who responded to the second-wave survey. There were no statistically significant differences between these two groups. Thus, we are confident that our sample represents the target population.

These R\&D subsidiaries had, on average, $93.8 \%$ equity investments from Japanese parent companies. Twenty-one percent of these subsidiaries were established as merged or acquired firms. Seventy-two percent of these subsidiaries are co-located with either manufacturing or marketing facilities. The sample is composed of automobile-related companies (24\%), electronics-related firms (24\%), pharmaceutical companies $(23 \%)$, and others such as chemical firms.

The average age of the subsidiaries was 12 years. There were, on average, $51 \mathrm{R} \& \mathrm{D}$ personnel at each subsidiary, representing $5.5 \%$ of the total number of R\&D personnel in the selected Japanese MNCs. ${ }^{12}$ Each subsidiary had, on average, 15 Japanese (expatriated) R\&D personnel. Fifty-five percent of the respondents (i.e., top managers) were Japanese.

\section{B. Measurements}

Dependent Variables: Based on Kuemmerle [77], we measured four types of knowledge flows-i.e., Technical Knowledge Flow, Market Knowledge Flow, Sub-HQ Knowledge Flow, and Sub-Local Knowledge Flow - by asking respondents the extent to which their R\&D subsidiaries send/receive (a) technology-related know-how/information, and (b) market-related know-how/information from/to a R\&D subsidiary/HQ and from/to other R\&D subsidiaries, and from local environments-i.e., local universities, local governments, customers, suppliers, competitors-by using ten 5-point Likert scales. (See Appendix for details about our measures.)

We conducted a factor analysis (varimax-rotation) on these ten scales. The factor analysis identified one more factor for which: 1) the eigenvalue exceeded one, and 2) the reliability index (Cronbach alpha) among the scores exceeded 0.70. The factor consisted of technology- and market-related knowledge

\footnotetext{
${ }^{11}$ We found that Odagiri and Yasuda [105] also used the Toyo Keizai's data for their quantitative analysis of overseas R\&D by Japanese MNCs. However, they double-checked the data by using another database created by METI (Ministry of Economy, Trade and Industry).

${ }^{12}$ This percentage $(5.5 \%)$ was derived from $60 \%$ of the respondents-i.e., $40 \%$ were missing values. Thus, we decided not to use this percentage for our later analyses.
}

flows between an R\&D subsidiary and other subsidiaries. We included this factor-labeled as Sub-Sub Knowledge Flow-as an additional dependent variable in order to further explore our framework.

Accordingly, we have five types of knowledge flows. The first two types-i.e., Technical Knowledge Flow and Market Knowledge Flow - are regarding "what" or "contents" of flowing knowledge, while the other three types-i.e., Sub-HQ Knowledge Flow, Sub-Local Knowledge Flow and Sub-Sub Knowledge Flow-are regarding "where" or "places" of flowing knowledge. 13

Independent Variables: $R \& D$ Strategy consists of $H B A$ Strategy and HBE Strategy. By following Kuemmerle [77], $H B A$ Strategy was measured by two question items describing a home-base augmenting R\&D subsidiary, while HBE Strategy was measured by three question items describing a home-base exploiting R\&D subsidiary. Following Hedlund [60], $A u-$ tonomy was measured using five questions items describing the degree to which each subsidiary is localized in its employment, and decentralized or autonomous in its decision-making. By extending Minbaeva et al. [91], Incentive was measured using four Likert-type questions regarding 1) attitude or commitment, 2) leadership, 3) teamwork, and 4) potential capabilities.

Control Variables: Yoshihara et al. [135] and Westney [133] suggested the tendency of Japanese R\&D facilities to be located with their manufacturing/marketing facilities abroad. Thus, a control variable (a dummy), Co-location, was included in our analyses. Mergers/acquisitions and greenfield developments are the two most common methods of establishing R\&D subsidiaries abroad [25]. Thus, we also included $M \& A$ as a control (dummy) variable. It is possible that the longer a subsidiary has been established in US, the more efficient it has become in its knowledge flow management. Thus, Subsidiary Experience was also measured by the number of years an R\&D subsidiary had been established in US.

The larger subsidiaries may have more autonomy [132], or may require more parents' attentions [60]. Thus, Sub Size was included, by measuring the number of R\&D personnel in a subsidiary. We also measured the size of each parent company, HQ Size, by the total number of employees. Firms in pharmaceuticals, chemicals, plastics, ceramics, and metal products were assumed to have different attitudes toward intellectual properties from firms in electrical appliances, automobiles and parts, transport equipment, and precision machines [95]. Thus, firms in the former industries-considered "mono technology-based firms"- were coded as 0 , while those in the latter industries-considered "system technology-based firms" were coded as 1 .

Knowledge Accumulation and Performance: We argue that knowledge accumulations and subsidiaries' performance should be measured by using a variety of objective measures-e.g., number of patents, copyrights, papers, or new products-as

\footnotetext{
${ }^{13}$ As hypothesized, the former two knowledge flows-i.e., Technical Knowledge Flow and Market Knowledge Flow-and the latter three knowledge flows-i.e., Sub-HQ Knowledge Flow, Sub-Local Knowledge Flow, and Sub-Sub Knowledge Flow-are not mutually exclusive. For example, an original score was used for both Technical Knowledge Flow and Sub-HQ Knowledge Flow. All these five types of knowledge flows had their reliability indices (Cronbach alphas) higher than 0.65 (See Table II).
} 


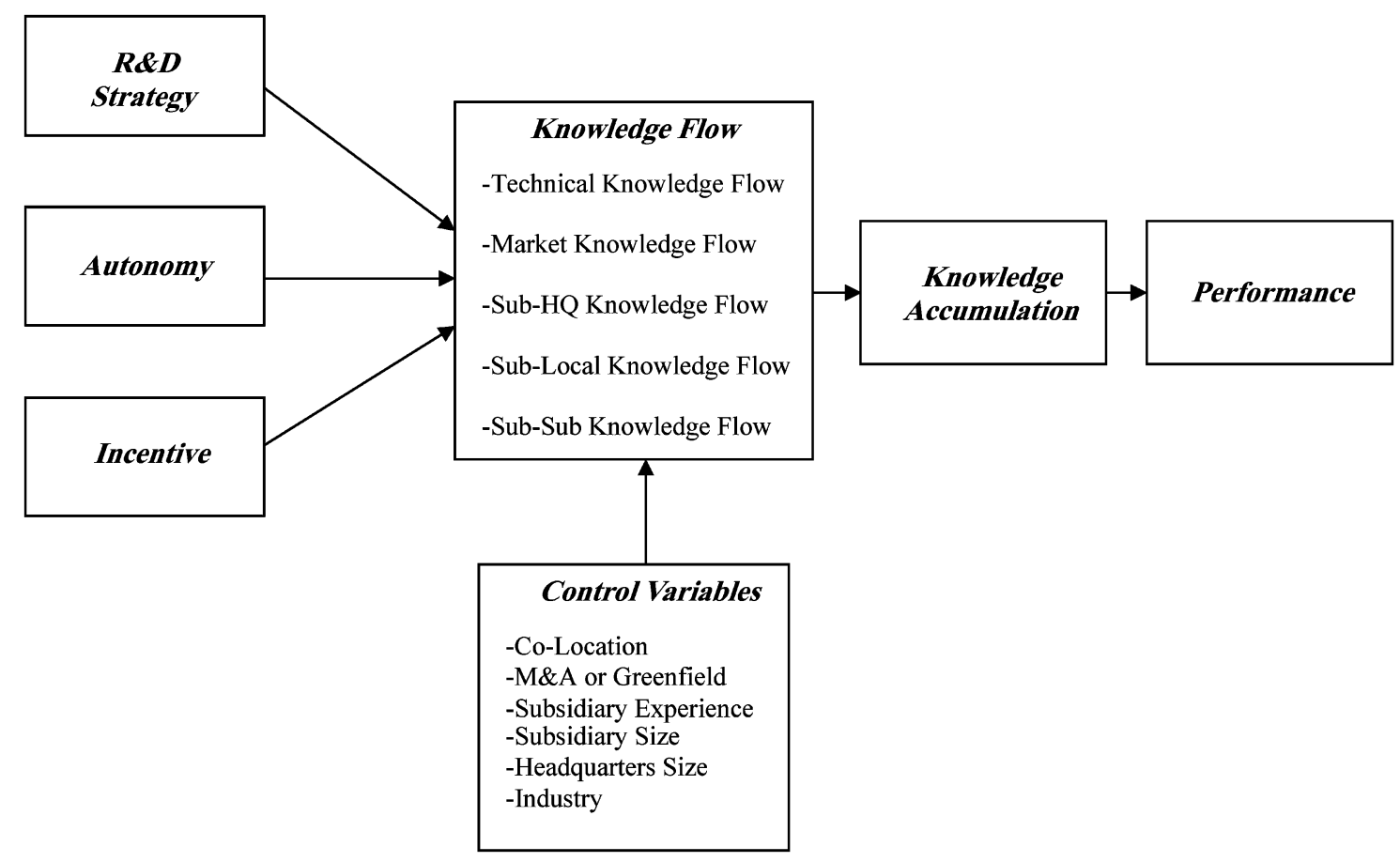

Fig. 1. Determinants of global knowledge flows and performance.

well as subjective measures-e.g., Likert-scales-because subsidiaries in different industries must have different strategic priorities, thus requiring performance data to be adjusted [50].

Although patents are frequently used in previous studies to measure a level of knowledge accumulations [95], "meanings" of patents seem to differ significantly across firms. For example, firms with high manufacturing process technologies usually do not file patents because of fear of information leaks [26].

Our preliminary interviews with the seven managers in these R\&D subsidiaries also revealed 1) home-base-augmenting subsidiaries tended to encourage paper publications; 2) home-baseexploiting subsidiaries tended to encourage paper publications; 3 ) subsidiaries in chemical and pharmaceutical industries generally tended to encourage both patent filing and paper publications; 4) subsidiaries in electronics and automobile industries generally tended to encourage patent filing, but discourage paper publications.

Studies on knowledge and technology transfer support our argument, as well. For example, Szulanski [120] used subjective measures of satisfaction with the process and/or outcome of knowledge transfers as proxy variables. Almeida et al. [6] also used combinations of quantitative and qualitative methods for knowledge transfer performance.

Furthermore, studies on multi-unit firms from the KBV also support our argument. For example, Tsai [126] employed an innovation achieved rate-i.e., the number of new products introduced in a unit in a particular year divided by the unit's target number in that year-to measure the performance of innovation in each unit.

Accordingly, the level of knowledge accumulation-Knowledge Accumulation - was measured both quantitatively and qualitatively. Quantitative Knowledge Accumulation consisted of two parts: 1) the number of published papers-named as Quantitative Knowledge Accumulation-1-and 2) the total number of patents awarded, copyrights awarded, and new products/services created by utilizing knowledge developed in a subsidiary—named as Quantitative Knowledge Асситиlation-2. Qualitative Knowledge Accumulation was measured by using three Likert-type question items asking respondents qualitatively about the level of knowledge accumulation at each subsidiary.

Finally, we measured subsidiaries' overall performance, as hypothesized. Overall Subsidiary Performance was measured using seven Likert-type questions asking respondents the extent to which their subsidiary had been successful in 1) technologies, 2) speed, 3) technical goals achieved, 4) financial goals achieved, 5) technical contributions to their parent company, 6) financial contributions to their parent company, and 7) overall assessment of a subsidiary's R\&D performance.

We employed the following two methods to avoid common method bias. First, the dependent variables were placed after the independent variables in the survey to diminish the effects of consistency artifacts. Second, Harman's single factor test was performed [57], [113]. The factor analysis revealed five factors with eigenvalues greater than 1.0 that accounted for $70.2 \%$ of the total variance. The first factor only accounted for $28.4 \%$ of the variance. These results suggested that common method variance was not a serious problem in our study.

Discriminant validity assesses the degree to which two theoretically similar constructs are distinct. Because of our multiple uses of the original ten scores in constructing the five knowledge flows, we conducted discriminant analyses by excluding the five knowledge flows. The results supported the discriminant validity, by using three criteria assessments proposed by Campbell and Fiske [23].

Fig. 1 represents our model. As discussed, the model consists of three independent variables $-R \& D$ Strategy, Autonomy, and 
TABLE II

DESCRIPTIONS AND CORRELATIONS AMONG THE DEFINED VARIABLES

\begin{tabular}{|c|c|c|c|c|c|c|c|c|c|c|c|c|c|c|c|c|c|c|c|c|c|}
\hline & Mean & $S D$ & 1 & $\underline{2}$ & 3 & 4 & 5 & 6 & 7 & $\boldsymbol{8}$ & $g$ & 10 & 11 & 12 & 13 & 14 & 15 & 16 & 17 & 18 & 19 \\
\hline 1.Technical Knowledge Flow & 2.643 & 0.678 & .735 & & & & & & & & & & & & & & & & & & \\
\hline 2.Market Knowledge Flow & 2.485 & 0.751 & $.761^{* * *}$ & .760 & & & & & & & & & & & & & & & & & \\
\hline 3.Sub-HQ Knowledge Flow & 2.965 & 0.679 & $.734^{* * *}$ & $.771^{* * *}$ & .694 & & & & & & & & & & & & & & & & \\
\hline 4.Sub-Local Knowledge Flow & 3.622 & 0.725 & $.545^{* * *}$ & $.490^{* * *}$ & $.397^{* * *}$ & .689 & & & & & & & & & & & & & & & \\
\hline 5 Sub-Sub Knowledge Flow & 1.635 & 1.051 & $.826 * * *$ & $.841^{* * *}$ & $.499 * * *$ & $281^{* *}$ & .889 & & & & & & & & & & & & & & \\
\hline 6. HBA Strategy & 3.274 & 1.02 & $.245^{* *}$ & .019 & .052 & -.052 & $.196^{*}$ & .801 & & & & & & & & & & & & & \\
\hline 7. Develop. Strategy & 3.578 & 0.902 & .181 & $.313^{* * *}$ & .162 & .102 & $.238^{* *}$ & .063 & .697 & & & & & & & & & & & & \\
\hline 8. Autonomy & 1.98 & 0.73 & .123 & .113 & .105 & $.277^{* *}$ & .040 & .174 & .093 & .734 & & & & & & & & & & & \\
\hline 9. Incentive & 3.197 & 0.483 & $.286^{* *}$ & .159 & $.247^{* *}$ & .112 & .177 & $.335^{* * *}$ & .010 & .054 & .690 & & & & & & & & & & \\
\hline 10. Co-Location & 0.506 & 0.503 & -.133 & -.002 & .029 & -.017 & -.117 & $-.266^{* *}$ & .115 & .147 & .088 & NA & & & & & & & & & \\
\hline 11. MSA & 0.178 & 0.37 & -.128 & .004 & .015 & -.061 & -.090 & -.094 & -.063 & $.265^{* *}$ & -.065 & .153 & $\mathrm{NA}$ & & & & & & & & \\
\hline 12. Experience & 12.067 & 9.804 & .031 & .054 & -.045 & .127 & .057 & -.024 & .142 & .067 & -.027 & .055 & .093 & NA & & & & & & & \\
\hline 13. Sub Size & 50.775 & 77.713 & $.226^{* *}$ & .151 & .044 & $.186^{*}$ & $.225^{* *}$ & $.271^{* *}$ & .166 & $.193^{*}$ & .017 & $-.273^{* *}$ & .021 & .111 & NA & & & & & & \\
\hline 14. HQ Size & 58004.08 & 87569 & -.143 & -.077 & -.114 & .053 & -.128 & .099 & -.007 & .111 & -.095 & $.224^{* *}$ & .041 & .032 & .170 & $\mathrm{NA}$ & & & & & \\
\hline 15. Industry & 0.316 & 0.468 & -.063 & .063 & .119 & .023 & -.078 & $-.224 * *$ & $.257^{* *}$ & -.083 & -.026 & $.181^{*}$ & -.007 & $.221 * *$ & .038 & -.110 & $\mathrm{NA}$ & & & & \\
\hline 16. Quantitative Know. Accum.- 1 & 0.721 & 1.269 & $.230^{* *}$ & .052 & .011 & $.197^{*}$ & .159 & $.327^{* * *}$ & -.107 & .093 & .079 & -.183 & -.054 & -.053 & .135 & .121 & $-312^{* * *}$ & NA & & & \\
\hline 17. Quantitative Know. Accum.- 2 & 1.899 & 2.577 & .093 & .068 & .020 & .111 & .086 & .166 & .042 & -.065 & .133 & .080 & .048 & .106 & .046 & .097 & -.151 & $.265 * *$ & .689 & & \\
\hline 18. Qualitative Know. Accum. & 2.559 & 0.840 & $.454 * * *$ & $.410^{* * *}$ & $.475^{* * *}$ & $291 * * *$ & $.326^{* * *}$ & $.317^{* * *}$ & $.318 * * *$ & .171 & $.220^{*}$ & -100 & -.019 & .012 & $.259 * *$ & .120 & .012 & .168 & .150 & .722 & \\
\hline 19. Overall Performance & 3.241 & 0.594 & $.276^{* *}$ & $.350^{* * *}$ & $.342^{* * * *}$ & $.380^{* * *}$ & .181 & $.294^{* * *}$ & .162 & $.257^{* *}$ & $.360^{* * *}$ & -.061 & .085 & .046 & .115 & .080 & -.110 & $.250^{* *}$ & $.249^{* *}$ & $.543^{* * * *}$ & .801 \\
\hline
\end{tabular}

Numbers are Pearson correlation coefficients; * $\mathrm{p}<0.10,{ }^{*} \mathrm{p}<0.05,{ }^{* * *} \mathrm{p}<0.01$ (two-tailed) Reliability index (Cronbach's alphas) are on the diagonal.

Incentive - and three dependent variables-Knowledge Flows, Knowledge Accumulation, and Overall Performance-and six control variables-Co-Location, $M \& A$, Subsidiary Experience, Subsidiary Size, HQ Size, and Industry.

\section{RESULTS}

Table II shows the descriptive statistics (mean and standard deviation) and correlation matrix among all of the defined variables-reliability indices (Cronbach's alphas) are also reported on the diagonal. The mean scores in the defined seven knowledge flows indicate that Sub-Local Knowledge Flow had the highest score (3.622), while Sub-Sub Knowledge Flow had the lowest score (1.635) - the difference was statistically significant at the one percent level by our t-test. 14

Since Gupta and Govindarajan [52] did not report a similar difference among their four types of knowledge flows, our data may indicate that knowledge flows from local environments to R\&D subsidiaries are generally high, while knowledge flows among overseas subsidiaries are generally low. Such low knowledge flows among subsidiaries may stem from Japanese MNCs' lack of experience, as compared with American and European MNCs.

There are high correlations among the five knowledge flows-Technical Knowledge Flow, Market Knowledge Flow,

\footnotetext{
${ }^{14}$ The first discriminant validity criterion-i.e., to ascertain the level of general method variance contained within the matrix-was met because values within the validity diagonal were significantly higher than the values contained within the heterotrait-heteromethod triangles in $98 \%$ of the cases. The second discriminant validity criterion-i.e., to ascertain if the validity diagonal coefficients are greater than the heterotrait-monomethod coefficients-was satisfied in $95 \%$ of the cases. The third discriminant validity criterion-i.e., to ascertain if the same pattern of trait interrelationships is found in both the heterotrait-heteromethod coefficients and the heterotrait-monomethod coefficients-was met, because Kendall's Coefficient of Concordance, W, was found to be .321 at p < .0001 which suggests that there is some similarity in the coefficient patterns. These results support the discriminant validity.
}

Sub-HQ Knowledge Flow, Sub-Local Knowledge Flow, and Sub-Sub Knowledge Flow. These high correlations suggest that special care must be taken to avoid multicollinearity problems in the following multi-regression analyses. ${ }^{15}$

There are also moderately high correlations between Qualitative Knowledge Accumulation and Overall Performance, and between Qualitative Knowledge Accumulation and the five knowledge flows. These correlations seem to suggest a possibility that high levels of knowledge flows generally lead to moderate levels of knowledge accumulation and overall performance.

A correlation between $M \& A$ and Autonomy (0.265) suggests that a site started by M\&A is likely to be more localized and decentralized. An association between Autonomy and Sub Size (0.193) implies that the longer a subsidiary operates in the US, the more localized and decentralized it becomes. An association between Incentive and HBA Strategy (0.335) also suggests that home-base-augmenting subsidiaries tend to have process-oriented incentive practices.

A positive correlation between HBA Strategy and Sub Size (0.271), and a negative correlation between HBA Strategy and Industry (-0.224) implies that large subsidiaries in mono-technology based industries tend to pursue home-base-augmenting strategies. There are also positive associations among $H B E$ Strategy, Experience, and Industry. These associations imply that home-base-augmenting subsidiaries tended to be in system technology-based industries such as automobile or electronics, and started their operations in the US earlier.

Co-Location indicated positive correlations with $H Q$ Size (0.224) and Industry (0.181), suggesting that R\&D subsidiaries with large parents in system-technology based industries tend

\footnotetext{
${ }^{15}$ Such high correlations were expected, because of our multiple uses of the original ten scores. Such high correlations among various types of knowledge flows were also reported by Gupta and Govindarajan [52].
} 
TABLE III

FACTORS AFFECTING Four TyPeS OF KNOWLEDGE Flows

\begin{tabular}{|c|c|c|c|c|c|}
\hline & $\begin{array}{c}\text { Technical } \\
\text { Knowledge } \\
\text { Flow } \\
\text { (1) }\end{array}$ & $\begin{array}{l}\text { Market } \\
\text { Knowledge } \\
\text { Flow } \\
\text { (2) }\end{array}$ & $\begin{array}{c}\text { Sub-HQ } \\
\text { Knowledge } \\
\text { Flow } \\
\text { (3) }\end{array}$ & $\begin{array}{c}\text { Sub-Local } \\
\text { Knowledge } \\
\text { Flow } \\
\text { (4) }\end{array}$ & $\begin{array}{c}\text { Sub-Sub } \\
\text { Knowledge } \\
\text { Flow } \\
\text { (5) }\end{array}$ \\
\hline \multicolumn{6}{|c|}{ INDEPENDENT VARIABLES } \\
\hline HBA Strategy & .094 & -.102 & .041 & $-.217 * *$ & .063 \\
\hline Develop. Strategy & .144 & $.308 * *$ & .154 & .017 & $.284 * *$ \\
\hline Autonomy & .060 & .033 & .048 & $.302 * *$ & -.072 \\
\hline Incentive & $.215^{*}$ & .183 & $.217^{*}$ & .153 & .129 \\
\hline \multicolumn{6}{|c|}{ CONTROL VARIABLES } \\
\hline Co-Location & -.104 & -.006 & .014 & -.016 & -.031 \\
\hline$M \& A$ & -.137 & .006 & .014 & -.174 & -.050 \\
\hline Experience & .054 & .045 & -.045 & .175 & .061 \\
\hline Sub Size & .174 & .118 & -.015 & $.209^{*}$ & .180 \\
\hline HQ Size & $-.208^{*}$ & .045 & -.117 & .024 & -.173 \\
\hline Industry & -.132 & -.060 & .073 & -.055 & -.193 \\
\hline$R^{2}$ & .222 & .244 & .126 & .225 & .210 \\
\hline Adjusted $R^{2}$ & .072 & .104 & .002 & .074 & .068 \\
\hline$F$ & 1.223 & $1.344 *$ & .780 & 1.255 & 1.143 \\
\hline
\end{tabular}

Numbers are standardized beta; ${ }^{*} \mathrm{p}<0.10,{ }^{* *} \mathrm{p}<0.05$

to co-locate their facilities with their manufacturing facilities. Co-Location also indicated negative correlations with $H B A$ Strategy (-0.266) and Sub Size (-0.273), suggesting that larger home-base-augmenting $\mathrm{R} \& \mathrm{D}$ subsidiaries are not likely to co-locate with their manufacturing facilities.

As we hypothesized, we have three models to test seven hypotheses. Hypotheses 1-5 were concerned with the determinants of knowledge flows. Hypothesis 6 is related to the determinants of knowledge accumulation. Finally, Hypothesis 7 is concerned with the determinants of the overall performance of subsidiaries. Thus, in order to test these hypotheses, we conducted three series of multi-regression analyses-i.e., knowledge flows, knowledge accumulation, and overall performance, as three dependent variables. Table III presents the first series of regression analyses.

Column 1 in Table III presents the relationships between the independent variables and Technical Knowledge Flow among a subsidiary, its parent company, other subsidiaries and its local environment. There is no significant beta coefficient between $R \& D$ Strategy (HBA Strategy and HBE Strategy) and Technical Knowledge Flow, thus lending no support for Hypothesis 1-home-base-augmenting $\mathrm{R} \& \mathrm{D}$ subsidiaries are likely to promote technology-related knowledge flows among the subsidiary, its parent company, other subsidiaries and its local environment.
Column 1 does indicate, however, that Technical Knowledge Flow has a highly positive association with Incentive, suggesting that process-based incentives encourage technical knowledge flows. Column 1 also indicates that larger subsidiaries tend to discourage such technical knowledge flows. We found that the size of the parent companies in the pharmaceutical industry were significantly smaller than those in other industries, and that our regression analyses when excluding these pharmaceutical companies did not show such a significant beta. Thus, the result seems to indicate that R\&D subsidiaries in the pharmaceutical industry depend on more technical knowledge flows.

Column 2 in Table III reports the relationships between Market Knowledge Flow and the defined independent variables. The results provide support for Hypothesis 2-home-base-exploiting R\&D subsidiaries are likely to promote market-related knowledge flows among the subsidiary, its parent company, other subsidiaries and its local environment.

Column 3 in Table III examines the relationships between $H Q$-Sub Knowledge Flow and the independent variables. The results do not support Hypothesis 4-the greater autonomy of an R\&D subsidiary, the lower the knowledge flows between the subsidiary and its parent company. (The reason for this will be examined further in Section V.) However, the results in Column 3 do support Hypothesis 5 -the more process-oriented incentive 
TABLE IV

FACTORS AFFECTING KNOWLEDGE ACCUMULATION

\begin{tabular}{|c|c|c|c|c|c|c|c|c|c|c|c|c|c|c|c|}
\hline & \multicolumn{5}{|c|}{$\begin{array}{l}\text { Quantitative Knowledge } \\
\text { Accumulation-1 } \\
\text { (Paper) }\end{array}$} & \multicolumn{5}{|c|}{$\begin{array}{c}\text { Quantitative Knowledge } \\
\text { Accumulation-2 } \\
\text { (Patent, Copyright, Product) }\end{array}$} & \multicolumn{5}{|c|}{$\begin{array}{c}\text { Qualitative Knowledge } \\
\text { Accumulation }\end{array}$} \\
\hline & 1 & 2 & 3 & 4 & 5 & 6 & 7 & 8 & 9 & 10 & 11 & 12 & 13 & 14 & 15 \\
\hline \multicolumn{16}{|l|}{ INDEPENDENT VARIABLES } \\
\hline Technical Knowledge Flow & .203 & & & & & .029 & & & & & $.349^{* * *}$ & & & & \\
\hline Market Knowledge Flow & & .099 & & & & & .062 & & & & & $.316^{* * *}$ & & & \\
\hline Sub-HQ Knowledge Flow & & & .060 & & & & & .030 & & & & & $.428^{* * *}$ & & \\
\hline Sub-Local Knowledge Flow & & & & $.274^{* *}$ & & & & & .216 & & & & & $.295^{* *}$ & \\
\hline Sub-Sub Knowledge Flow & & & & & .121 & & & & & .015 & & & & & .167 \\
\hline HBA Strategy & .214 & $.240^{*}$ & $.231^{*}$ & $.301^{* *}$ & .222 & .144 & .170 & .163 & .031 & .162 & .133 & .194 & .168 & .197 & .149 \\
\hline Develop. Strategy & -.113 & -.114 & -.092 & -.105 & -.119 & .039 & .027 & .042 & -.249 & .042 & $.231 * *$ & .186 & $.225^{* *}$ & $.259^{* *}$ & $.234^{*}$ \\
\hline Autonomy & .046 & .047 & .049 & -.031 & .059 & -.143 & -.191 & -.189 & .038 & -.188 & .031 & .028 & .029 & -.050 & .049 \\
\hline $\begin{array}{l}\text { Incentive } \\
\text { CONTROL VARIABLES }\end{array}$ & -.041 & -.013 & -.010 & -.046 & -.011 & .072 & .065 & .069 & .203 & .076 & .108 & .130 & .083 & .132 & .167 \\
\hline Co-location & -.048 & -.056 & -.059 & -.025 & -.059 & .164 & .179 & .177 & .106 & .107 & -.126 & -.132 & -.129 & -.111 & -.146 \\
\hline $\boldsymbol{M \& A}$ & -.023 & -.049 & -.049 & -.006 & -.042 & .076 & .074 & .074 & .074 & .076 & .065 & .020 & .012 & .069 & .032 \\
\hline Experience & -.048 & -.037 & -.031 & -.077 & -.040 & .087 & .104 & .108 & .037 & .107 & -.078 & -.066 & -.040 & -.099 & -.062 \\
\hline Sub Size & .024 & .048 & .058 & .026 & .036 & .048 & .055 & .062 & .003 & .059 & .039 & .064 & .097 & .061 & .066 \\
\hline HQ Size & .106 & .076 & .075 & .047 & .090 & .012 & .023 & .022 & -.203 & .022 & .192 & .153 & .171 & .106 & .158 \\
\hline Industry & -.188 & $-.209^{*}$ & $-.219 *$ & $-.201^{*}$ & $-.192 *$ & -.196 & -.206 & -.211 & .205 & -.207 & .065 & .036 & -.010 & .026 & .050 \\
\hline$R^{2}$ & .226 & .202 & .197 & .255 & .255 & .120 & .120 & .118 & .115 & .117 & .331 & .321 & .401 & .306 & .257 \\
\hline $\begin{array}{c}\text { Adjusted } R^{2} \\
F\end{array}$ & .066 & .037 & .020 & .087 & .086 & .002 & .003 & .001 & .001 & .002 & .201 & .198 & .274 & .198 & .087 \\
\hline$F$ & 1.323 & 1.102 & 1.098 & 1.455 & 1.456 & 0.800 & 0.789 & 0.780 & 0.770 & 0.790 & $2.304 * * *$ & $2.100 * *$ & $3.234 * * *$ & $2.231 * *$ & .1 .536 \\
\hline
\end{tabular}

Numbers are standardized beta $;{ }^{*} \mathrm{p}<0.10,{ }^{* *} \mathrm{p}<0.05,{ }^{* * *} \mathrm{p}<0.01$

practices used in an R\&D subsidiary, the higher the knowledge flows between the subsidiary and its parent company.

Column 4 in Table III reports the relationships between Sub-Local Knowledge Flow and the independent variables. Autonomy shows a significantly high association with Sub-Local Knowledge Flow, thus supporting Hypothesis 3-the greater autonomy of an R\&D subsidiary, the higher the knowledge flows from its local environment.

Column 4 also shows that HBA Strategy tends to discourage Sub-Local Knowledge Flow. Sub-Local Knowledge Flow consists of two indicators-1) technology-related knowledge flows from local environments, and 2) market-related knowledge flows from local environments to the U.S. subsidiary. Further regression analyses using the two original dependent variables showed that market-related knowledge flows had a highly negative beta with HBA Strategy, while technology-related knowledge flow did not. Thus, results seem to partially support our assumption that HBA Strategy discourages market-related knowledge flows.

Column 4 indicates that Sub-Local Knowledge Flow tends to be greater when the subsidiary is large. This result is understandable because larger subsidiaries (measured by number of R\&D personnel) tend to develop more networks with local environments such as local universities, local governments, customers, suppliers, and/or competitors.

Column 5 in Table III reports the relationships between Sub-Sub Knowledge Flow and the independent variables. Column 5 shows that Sub-Sub Knowledge Flow tends to be greater when the subsidiary employs HBE Strategy. This result supports Nobel and Birkinshaw [98] in the sense that some types of $\mathrm{R} \& \mathrm{D}$ subsidiaries encourage "lateral communications" among global R\&D subsidiaries, while others do not.

The above results can be summarized as follows: 1) since two of the five hypotheses were not supported, our results cast doubt on our types of knowledge flows; 2) a company's R\&D strategy seemed to determine levels of knowledge flows, especially market-related and lateral (subsidiary-subsidiary) knowledge flows; 3) Autonomy and Incentive had positive effects on knowledge flows; 4) control variables-i.e., Co-Location, $M \& A$, Experience, and Industry - generally had no significant effect on knowledge flows.

Knowledge Accumulation: Table IV examined the factors affecting these types of knowledge accumulations-i.e., Quantitative Knowledge Accumulation-1, Quantitative Knowledge Accumulation-2, and Qualitative Knowledge Accumulation. Since correlations among the five types of knowledge flows were very high, we conducted seven separate regression analyses for the three types of knowledge accumulations.

Column 1 to Column 5 examined factors affecting the number of papers in subsidiaries. Our regression analyses found that home-base-augmenting subsidiaries tend to have higher numbers of papers, because three out of the five regressions showed highly positive betas on HBA Strategy. These regression analyses also indicated that Industry had highly negative associations with the number of papers, suggesting that firms in pharmaceuticals, chemicals, plastics, ceramics, and metal products tend to publish more papers than those in electrical appliances, automobiles and parts, transport equipment, and precision machines.

Furthermore, Sub-Local Knowledge Flow in Column 4 of the table showed a highly positive association, thus, partially 
TABLE V

FACTORS AFFECTING R\&D SUbSIDIARIES’ Overall PERFORMANCE

\begin{tabular}{|c|c|c|c|c|c|}
\hline & \multicolumn{5}{|c|}{$\begin{array}{c}\text { Overall } \\
\text { Performance }\end{array}$} \\
\hline & $(1)$ & $(2)$ & (3) & (4) & $(5)$ \\
\hline \multicolumn{6}{|l|}{ INDEPENDENT VARIABLES } \\
\hline Technical Knowledge Flow & .106 & & & & \\
\hline Market Knowledge Flow & & $.271^{* *}$ & & & \\
\hline Sub-HQ Knowledge Flow & & & $.272 * *$ & & \\
\hline Sub-Local Knowledge Flow & & & & $.318^{* *}$ & \\
\hline Sub-Sub Knowledge Flow & & & & & -.046 \\
\hline HBA Strategy & .041 & .079 & .054 & .140 & -.032 \\
\hline Develop. Strategy & .134 & .068 & .113 & .128 & .046 \\
\hline Autonomy & $.271^{* *}$ & $.263 * *$ & $.267^{* *}$ & .168 & $.239 * *$ \\
\hline Incentive & $.295^{* *}$ & $.271^{* *}$ & $.253^{* *}$ & $.264 * *$ & $.245^{* *}$ \\
\hline \multicolumn{6}{|l|}{ CONTROL VARIABLES } \\
\hline Co-location & -.131 & -.120 & -.124 & -.086 & -.058 \\
\hline$M \boldsymbol{d} A$ & -.117 & -.131 & -.136 & -.073 & -.135 \\
\hline Experience & .001 & -.003 & .015 & -.037 & .043 \\
\hline Sub Size & -.068 & -.077 & -.050 & -.085 & -.088 \\
\hline HQ Size & .102 & .103 & .109 & .059 & .012 \\
\hline Industry & -.042 & -.043 & -.075 & -.058 & -.066 \\
\hline Quantitative Know. Accum.-1 & .134 & .123 & .133 & .061 & .088 \\
\hline Quantitative Know. Accum.-2 & $.196^{*}$ & $.185^{*}$ & $.193^{*}$ & .142 & .145 \\
\hline Qualitative Know. Accum. & $.480 * * *$ & $.407 * * *$ & $.410^{* * *}$ & $.389 * * *$ & $.448^{* * *}$ \\
\hline$R^{2}$ & 426 & .442 & .432 & .464 & .454 \\
\hline Adjusted $R^{2}$ & 288 & .294 & .294 & .309 & .303 \\
\hline$F$ & $2.877 * * *$ & $2.988^{* * *}$ & $2.789 * * *$ & $3.034 * * *$ & $3.001 * * *$ \\
\hline
\end{tabular}

Numbers are standardized beta; $* \mathrm{p}<0.10, * * \mathrm{p}<0.05, * * * \mathrm{p}<0.01$

supporting Hypothesis 6-the higher knowledge flows among a subsidiary, its parent company, other R\&D subsidiaries and its local environment, the higher the level of knowledge a subsidiary tends to accumulate.

Column 6 to Column 10 of Table IV indicates that there was no statistically significant beta regarding Quantitative Knowledge Accumulation-2-i.e., total number of patents, copyrights, and new products/services. Specifically, we did not find any association with the four types of knowledge flows, thus lending no support to Hypothesis 6. (The reason for this will be examined further in the following section.)

Column 11 to Column 15 of the table indicates highly positive associations between Qualitative Knowledge Accumulation and the five types of knowledge flows-Technical Knowledge Flow, Market Knowledge Flow, HQ-Sub Knowledge Flow, Sub-Local
Knowledge Flow, and Sub-Sub Knowledge Flow-thus, partially supporting Hypothesis 6 .

Highly positive betas were also found regarding $H B E$ Strategy, suggesting that home-base-exploiting subsidiaries tend to accumulate a high level of qualitative knowledge. It should also be noted that strategic factors, such as HBA Strategy and $H B E$ Strategy, contributed positively to knowledge accumulations, while organizational factors, such as Autonomy and Incentive, did not. ${ }^{16}$

Overall Performance: Table V shows our regression analyses on subsidiaries' overall performance. Since correlations among the five types of knowledge flows were very high, we conducted

\footnotetext{
${ }^{16}$ Tests for multicolinearity did not reveal any serious problems in the 21 regression analyses in Table IV. The values for the variance inflation factor (VIF) used to check for multicolinearity were all below 1.9.
} 
five separate regression analyses. The table indicated that three out of the five types of knowledge flows had significantly positive betas-i.e., Market Knowledge Flow, Sub-HQ Knowledge Flow, and Sub-Local Knowledge Flow.

The table also indicates that knowledge accumulation, especially Qualitative Knowledge Accumulation, significantly contributes to the subsidiaries' overall performance, moderately supporting Hypothesis 7-the higher the level of knowledge an R\&D subsidiary accumulates, the higher the subsidiary's performance.

Since the three types of knowledge accumulations seem to contribute more to the overall performance than do the five types of knowledge flows, these results may suggest the validity of our assumptions in this study-i.e., "knowledge flows are cost-involving activities" and "knowledge accumulations lead to high performance."

Furthermore, Table $\mathrm{V}$ indicates that both Autonomy and Incentive-organizational factors-had highly positive betas, suggesting that autonomous $\mathrm{R} \& \mathrm{D}$ subsidiaries with process-oriented incentives tend to have high overall performance, while strategic factors such as HBA Strategy and HBE Strategy do not. This finding suggests the importance of organizational factors (rather than strategic factors) for subsidiaries' overall performance. 17

\section{DISCUSSION}

This study attempts to fill a gap in the literature on the knowledge-based view of MNCs by measuring the impact of knowledge flows on knowledge accumulations and overall performance in R\&D subsidiaries of Japanese MNCs in the US. The study's survey results provide partial support for our model in Fig. 1, because three out of the seven hypotheses (Hypothesis 2, 3 and 5) were fully supported, and two hypotheses (Hypothesis 6 and 7) were partially supported.

However, Hypothesis 1 - the more basic research-oriented an R\&D subsidiary, the higher the technology-related knowledge flows among the subsidiary, its parent company, other R\&D subsidiaries and its local environment-and Hypothesis 4-the greater autonomy of an R\&D subsidiary is, the lower the knowledge flows between the subsidiary and its parent company-were not substantiated. Although not reported here, we conducted further analyses to help us understand these findings. We found a similar reason why these two hypotheses were not supported.

Hypothesis 1 was constructed based on the assumption that a more basic research-oriented R\&D subsidiary would encourage two-way (or six-way) knowledge flows among the subsidiary, its local environment and its parent company. However, further analyses suggested that home-base-augmenting subsidiaries tended to encourage technology-related knowledge flows from the subsidiary to its parent company, while discouraging technology-related knowledge flows from the parent company

\footnotetext{
${ }^{17}$ In order to test mediation effects between knowledge flows and accumulations on performance, we conducted regression analyses by including interaction terms. All the variables were mean centered in order to avoid multicollinearity problems [112]. We found that there are some mediation effects between knowledge flows and accumulations. However, these interaction effects were statistically significant at the 10 percent level, but not significant at the 5 percent level.
}

to the subsidiary. Thus, HBA Strategy tended to cancel the summed effects on the technology-related knowledge flows. ${ }^{18}$

Hypothesis 4-the greater autonomy of an R\&D subsidiary, the lower the knowledge flows between the subsidiary and its parent company-was constructed based on our assumption that greater autonomy of R\&D subsidiaries would discourage two-way knowledge flows between the R\&D subsidiaries and their parent companies.

However, further analyses suggested that the greater autonomy of R\&D subsidiaries encouraged knowledge flows from the subsidiary to its parent company, while discouraging knowledge flows from the parent company to the subsidiary. We constructed our hypotheses based on the assumption that knowledge flows are reciprocal-i.e., not unidirectional. However, our results revealed that this assumption is not valid in the relationship between HQs and subsidiaries. ${ }^{19}$

By including three types of knowledge accumulation indicators, our analyses partially supported Hypothesis 6-the higher the knowledge flows among an R\&D subsidiary, its parent company, other R\&D subsidiaries and its local environments, the higher the level of knowledge the subsidiary tends to accumulate. Although Qualitative Knowledge Accumulation supported the hypothesis, Quantitative Knowledge Accumulation-2 did not support the hypothesis.

Although not reported here, we conducted further regression analyses, by 1) using the original three indices-patents, copyrights, and new products/services - and 2) including curvilinear items for the four types of knowledge flows. We found some statistically significant curvilinear associations, for example, between New Products/Services and Sub-Local Knowledge Flow. Fig. 2 shows this relationship graphically. The results seem to partially substantiate our assumption that knowledge flows are cost-involving activities.

In the new product development (NPD) literature, several empirical studies have shown that too much information or knowledge flows occasionally hurt NPD performance-e.g., Kurokawa et al. [79], Sicotte and Langley [118], and Ottum and Moore [107]. Thus, our current study may suggest "an optimum level of knowledge flows."

Hypothesis 7-the higher the level of knowledge an R\&D subsidiary accumulates, the higher the subsidiary's performance-seems to be moderately supported, because Qualitative Knowledge Accumulation and Quantitative Knowledge Accumulation generally showed positive associations with subsidiaries' overall performance, as seen in Table V. Table V also shows that three out of the five types of knowledge flows had

\footnotetext{
${ }^{18}$ We conducted regression analyses by using original knowledge flow scores, as dependent variables. Our analyses indicated that HBA Strategy had a highly negative beta (-0.201) on technology-related knowledge flow from HQ to sub, while HBA Strategy had a highly positive beta $(0.286)$ on technology-related knowledge flow from sub to HQ.

${ }^{19} \mathrm{We}$ conducted regression analyses by using original knowledge flow scores, as dependent variables. Our analyses indicated that Autonomy had a highly negative beta (-0.234) on technology-related knowledge flow from $H Q$ to $s u b$ and a highly negative beta $(-0.256)$ on market-related information flow from $H Q$ to $s u b$. On the other hand, our analyses also indicated that Autonomy had a highly positive beta (0.278) on technology-related knowledge flow from sub to $H Q$ and a highly positive beta (0.289) on market-related information flow from $\mathrm{HQ}$ to sub.
} 


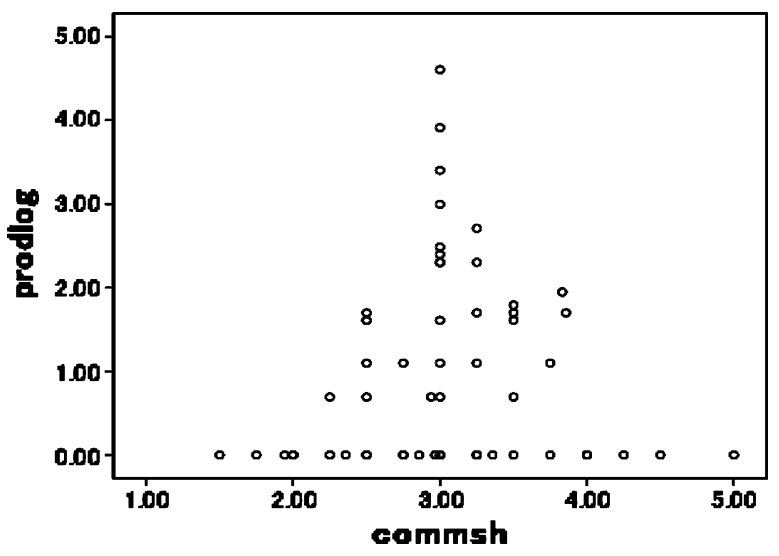

Fig. 2. A curvilinear relationship between knowledge flows and quantitative knowledge accumulation.

highly positive associations with overall performance-i.e., the higher the knowledge flows, the higher the performance. Thus, our results seem to substantiate the knowledge-based view of MNCs [52], [64].

Table V indicates that Market Knowledge Flow had a highly positive association with subsidiaries' overall performance, while Technical Knowledge Flow did not. Our finding supports Subramaniam and Venkatraman [119] in that market-related knowledge flows tended to contribute to performance more than technology-related knowledge flows did. In the NPD literature, studies also showed that market-related information or knowledge flows tend to contribute to NPD performance more than technical information or knowledge flows do-e.g., Kurokawa et al. [79].

Furthermore, Table V shows that vertical knowledge flows (i.e., Sub-HQ Knowledge Flow) had highly positive associations with overall performance, while horizontal knowledge flow (i.e., Sub-Sub Knowledge Flow) did not. These results support Gupta and Govindarajan [52, p. 490] in that "the parent corporation continues to serve as the most active creator and diffuser of knowledge within the corporation."

As discussed, Japanese MNCs tend to: 1) establish more recently smaller-scaled R\&D subsidiaries; 2) co-locate with their manufacturing/marketing facilities; 3 ) maintain stronger headquarter control over their R\&D subsidiaries by sending expatriates; 4) give priority to development and design for manufacturability, and the associated speed of new product introduction; $5)$ be developing international network of basic research.

We confirmed the first and second characteristics of Japanese R\&D subsidiaries by our data. However, the rest of the characteristics were neither confirmed nor suggested by our data. Thus, in order to supplement our findings, we interviewed ten parent companies in Japan by randomly selecting from the survey respondents.

By reflecting our survey population, we selected three companies in the automobile industry, four in the electronics industry, and three in the pharmaceutical industry. We interviewed with either chief technology officers (CTOs) or top managers in charge of global R\&D subsidiaries for approximately two hours.
We took unstructured (open-end) approach in order to find factors unidentified in our survey results. Most of interviews were tape-recorded with the approval of interviewees.

We found the following three tendencies from these interviews at HQs: 1) managers at HQs generally tended to underestimate the performance of their R\&D subsidiaries in the US, in line with [135]; 2) managers at HQs tended to point out serious communication and language problems between HQs and their subsidiaries, as well as between Japanese expatriates and American researchers, in line with [10] and [11]; 3) MNCs with strong corporate culture - e.g., Toyota, Canon and Panasonic - tended to develop special methods to solve knowledge flow problems, in line with [133].

These findings seem to be consistent with the characteristics of Japanese R\&D subsidiaries reported in previous case studies, in the sense that Japanese MNCs attempt to maintain stronger headquarter control over their global R\&D subsidiaries, by setting high performance goals for prompt introductions of new products in a global scale. ${ }^{20}$

\section{CONCLUSION}

This study attempts to fill a gap in the literature on the knowledge-based view of MNCs by focusing on R\&D subsidiaries of Japanese MNCs. We had the following five research questions: 1) what factors will determine knowledge flows among R\&D subsidiaries, headquarters (HQ), and other R\&D subsidiaries?; 2) what factors will determine knowledge accumulations of R\&D subsidiaries?; 3) what factors will determine performance of R\&D subsidiaries?; 4) how should R\&D subsidiaries manage knowledge flows for higher performance?

Regarding the first research question-i.e., factors determining knowledge flows-we found that R\&D strategies generally determine levels of knowledge flows, especially market-related and horizontal knowledge flows. We also found that R\&D strategies tended to cancel the summed effects of the technology-related knowledge in-flows and out-flows between HQ and subsidiaries.

Furthermore, we found that process-oriented incentives stimulate knowledge flows. The previous studies on the KBV of MNCs found that autonomous R\&D subsidiaries promote knowledge flows [52] and that network-linked (i.e., HQ or other subsidiaries-linked) incentives stimulate knowledge flows [40], [91]. Thus, our findings may be unique, although Iwata [70] also found similar results among American and European R\&D subsidiaries in Japan. ${ }^{21}$

Regarding the second research question-i.e., factors determining knowledge accumulations - we found that strategic factors, such as home-base-exploiting or home-base-augmenting

\footnotetext{
${ }^{20}$ Furthermore, we found the following three industry-specific tendencies from the interviews: 1) knowledge flows from HQs to subsidiaries tended to be well managed in the automobile industry; 2) knowledge flows from subsidiaries to HQs tended to be poorly managed in the electronics industry; 3) knowledge flows between subsidiaries and HQs tended to be poorly managed in the pharmaceutical industry.

${ }^{21}$ The previous studies have identified that Japanese companies generally tend to emphasize process-oriented incentives than American and European counterparts-e.g., Kagono et al. [74]. Thus, our finding may simply reflect such Japanese companies' characteristics.
} 
strategies, were more likely to determine knowledge accumulations than were organizational factors, such as autonomous subsidiaries, or incentive practices.

Regarding the third research question-i.e., factors determining performance-we found that market-related and vertical knowledge flows tend to contribute more to overall performance than do technology-related and horizontal knowledge flows. Furthermore, we found that organizational factors were more likely to determine subsidiaries' overall performance than were strategic factors.

The above findings suggest that strategic factors tend to determine knowledge accumulations, while organizational factors tend to determine performance. Although we hypothesized that accumulated knowledge would directly lead to high performance, organizational factors may be intervening between accumulated knowledge and subsidiaries' overall performance.

Regarding the fourth research question, this study has several implications for managers in charge of global R\&D activities. First, our data analyses found that knowledge flows are more likely to be determined by managerial factors (i.e., R\&D strategies, autonomy and incentives) than contextual (control) variables such as co-location, M\&A, experience, and industry.

These findings suggest: 1) purposes and missions of R\&D strategies should be clearly defined before launching global R\&D sites, 2) subsidiaries should be allowed a higher level of autonomy for higher knowledge flows and performance, and 3) process-oriented incentive practices rather than outcome-oriented incentives should be emphasized.

Second, knowledge flows among HQs, R\&D subsidiaries, and other subsidiaries should be encouraged, because the level of knowledge flows had positive associations with knowledge accumulation and subsidiary performance. Specifically, market-related and vertical knowledge flows should be emphasized more than technology-related and horizontal knowledge flows. However, managers should also be cautious about costs of knowledge flows, because we found too much knowledge flow may endanger knowledge accumulations.

Finally, the amount of specific knowledge accumulations, such as number of patents, copyrights, and papers, should not be overemphasized as performance indicators, because these numbers were not necessarily related with subsidiaries performance. Such numbers seemed to vary depending upon specific companies or industries, as discussed.

Our theoretical contribution to the study of MNCs is to substantiate the knowledge-based view of MNCs by our three-stage model. First, we identified factors affecting knowledge flows. Next, we examined the extent to which knowledge flows lead to knowledge accumulations. Finally, we examined the extent to which knowledge accumulations lead to subsidiaries' overall performance. In general, we found that high levels of knowledge flows lead to high levels of performance.

Accordingly, this study provides moderate support for the knowledge-based view of MNCs. We also found that the defined control factors-e.g., co-location, M\&A, experience, and industry - did not significantly affect knowledge flows, knowledge accumulations, or subsidiaries' overall performance. These results seem to further substantiate the generality of the knowledge-based view of MNCs.

However, we also found that high levels of knowledge flows occasionally do not lead to high levels of knowledge accumula- tions and performance, supporting our assumption that knowledge flows are cost-involving activities. For example, an R\&D subsidiary might be able to achieve high performance without frequent knowledge flows from $\mathrm{HQ}$, because of its highly experienced top management who has already accumulated enough knowledge from running the subsidiary.

Our methodological contributions to the study of MNCs from the KBV were to measure 1) subsidiaries' R\&D strategies, 2) both technology- and market-related knowledge flows, 3) both vertical and horizontal knowledge flows, 4) both knowledge in-flows and out-flows, and 5) the effect of knowledge flows on knowledge accumulations and overall performance of subsidiaries.

However, the findings in this paper must be interpreted with care, because of the following limitations. First, although we argued that Japanese R\&D subsidiaries in the US represent the largest population, the largest population does not necessarily represent the average population. Thus, the external validity of this study could be severely limited.

Second, the long-term effects of knowledge flows on subsidiary performance, as well as the reverse effects-i.e., subsidiary's performance on knowledge flows - cannot yet be ascertained. Our interviews also revealed that managers at HQs generally tended to underestimate the performance of their R\&D subsidiaries. Finally, there are also some concerns about the discriminant validity of the five knowledge flows.

Accordingly, the opportunity for further research into global $R \& D$ management is substantial. For example, further research on German or Korean R\&D facilities in the US or Europe, as well as Japanese R\&D subsidiaries in Asia or Europe, would broaden our understanding of this subject. Several in-depth case studies would also clarify further the relationships among the variables defined in this study. Without such research, it is uncertain whether these findings are specific to the Japanese MNCs in the current study or if they represent MNCs in general.

\section{APPENDIX \\ MEASUREMENT}

\section{Dependent Variables}

Based on Kuemmerle [77], [78], we measured ten knowledge flows by asking respondents the extent to which their $\mathrm{R} \& \mathrm{D}$ subsidiaries send/receive (a) technology-related know-how/information, and (b) market-related know-how/information, from/to the subsidiaries/HQ. We used the word, "know-how/information flow" instead of "knowledge flow" in our original questions. Although "knowledge flow" is popular in academic worlds, we found that it was not popular among practicing managers during our preliminary study with seven managers. We used 5-point Likert scales ( $1=$ not significant at all, $5=$ highly significant). In order to illustrate an extreme case where there is no information flow at all, we added " 0 " for no information flows at all.

Technical Knowledge Flow was measured by: 1) technology-related know-how/information flows from local environments to the U.S. subsidiary, 2) technology-related know-how/information flows from the R\&D subsidiary to HQ, 3) technology-related know-how/information flows from HQ to the U.S. subsidiary, 4) technology-related know-how/information flows from the U.S. subsidiary to other R\&D subsidiaries, 
and 5) technology-related know-how/information flows from other R\&D subsidiaries to the U.S. subsidiary. The Cronbach alpha among these five variables was 0.735 .

Market Knowledge Flow was measured by: 1) market-related know-how/information flows from local environments to the U.S. subsidiary, 2) market-related know-how/information flows from the R\&D subsidiary to HQ, 3) market-related know-how/ information flows from HQ to the U.S. subsidiary, 4) market-related know-how/information flows from the U.S. subsidiary to other R\&D subsidiaries, and 5) market-related know-how/information flows from other R\&D subsidiaries to the U.S. subsidiary. The Cronbach alpha among these five variables was 0.760 .

Sub-HQ Knowledge Flow was measured by: 1) technology-related know-how/information flows from HQ to the U.S. subsidiary, 2) market-related know-how/information flows from HQ to the U.S. subsidiary, 3) technology-related know-how/information flows from the U.S. subsidiary to HQ, and 4) market-related know-how/information flows from the U.S. subsidiary to HQ. The Cronbach alpha among these four variables was 0.694 .

Sub-Local Knowledge Flow was measured by 1) technology-related know-how/information flows from local environments-e.g., local universities, local governments, customers, suppliers, competitors - to the U.S. subsidiary, and 2) market-related know-how/information flows from local environments to the U.S. subsidiary. The Cronbach alpha between these two variables was 0.689 .

Sub-Sub Knowledge Flow was measured by 1) technologyrelated knowledge flows from the focused R\&D subsidiary to other R\&D subsidiaries, and 2) technology-related knowledge flows from other R\&D subsidiaries to the R\&D subsidiary, 3) market-related knowledge flows from the focused R\&D subsidiary to other R\&D subsidiaries, 4) market-related knowledge flows from other R\&D subsidiaries to the R\&D subsidiary. This variable was constructed by our factor analysis (varimax-rotation) among the ten scales of knowledge flows. We included this variable as an additional dependent variable in order to further explore our framework. The Cronbach alpha was 0.889 .

Quantitative Knowledge Accumulation was measured by: 1) the number of patents awarded, 2) the number of copyrights awarded, and 3) the number of published papers, and 4) the number of new products by using technologies and designs developed in a R\&D subsidiary. We conducted a factor analysis (Varimax rotation) and found two factors. One factor is the number of published papers. Another factor consists of the number of patents, the number of copyrights, and the number of new products. This factor is called Quantitative Knowledge Accumulation-1. The Cronbach alpha among the three indicators was 0.689—called Quantitative Knowledge Accumulation-2.

Qualitative Knowledge Accumulation was measured by the following three questions based on a 5-point Likert scale ( $1=$ not at all, 5=significantly): 1) to what extent, have you produced unique $\mathrm{R} \& \mathrm{D}$ results, by combining knowledge in your subsidiary and knowledge from your HQ?; 2) to what extent, have you produced unique $R \& D$ results by combining knowledge in your subsidiary and knowledge from your marketing and manufacturing sites in the US?; 3) to what extent have your
R\&D personnel advised or helped your parent company and other R\&D subsidiaries? The Cronbach alpha among the three indicators was 0.722 .

Overall Subsidiary Performance was measured by 7 Likettype questions, by asking respondents the extent to which their R\&D subsidiary had been successful in the following: 1) unique technologies developed, 2) speed to produce visible technical results, 3) technical goals achieved, 4) financial goals achieved, 5) technical contributions to their parent company, and 6) financial contributions to their parent company (1=very low, 5=very high). We also asked respondents for their overall assessment of the subsidiary's R\&D performance (1=not successful at all, $5=$ very successful). The Cronbach alpha for this measure was 0.801 .

\section{Independent Variables}

$\boldsymbol{R} \& \boldsymbol{D}$ Strategy was measured by asking respondents the extent to which they agreed with the following five statements on five-point scales ( $1=$ strongly agree, $5=$ strongly disagree): 1 ) we started this site to strengthen our R\&D capabilities by conducting R\&D in the US where some areas of technologies are advanced, 2) we started this site to take advantage of a better R\&D environment in the United States, 3) we started this site to employ and utilize researchers/engineers in the United States, 4) we started this site to be able to promptly respond to the needs of the U.S. market, and 5) we started this site to establish an integrated system ranging from $R \& D$ to production to sales in the U.S. market. The first three questions describe a home-base enhancing R\&D subsidiary, while the fourth and fifth questions depict a home-base exploiting R\&D subsidiary [77], [78]. The Cronbach alpha for the first three questions was 0.801 and 0.697 for the fourth and fifth questions. We call the first R\&D strategy HBA Strategy, and the second, HBE Strategy.

Autonomy was measured by using five variables: 1) the number of U.S. researchers/engineers as a percentage of the total number of researchers/engineers in the R\&D subsidiary, 2) a dummy variable coded "one" if the top manager was American and "zero" if he/she was Japanese (there were no third country nationals), 3) we asked respondents how autonomous their R\&D activities were from the parent company in terms of fund allocation, objectives and methods, on a 5-point scale (1=completely autonomous, 5=fully controlled), 4) we asked respondents what type of human resource management system was used in the subsidiary, and 5) we also asked respondents what type of R\&D management system was used in the subsidiary. The latter two measures used a 5-point scale $(1=100 \%$ Japanese style, $5=100 \%$ U.S. style). After normalizing each variable, we took an average. The Cronbach alpha for this construct was 0.734 .

Incentive was measured by asking respondents about whether R\&D personnel are evaluated on: 1) specific R\&D performance such as patents or papers, 2) achieved goals 3) leadership, 4) attitude or commitment, 5) teamwork, and 6) potential capabilities ( $1=$ not at all; 5=significantly). We also asked respondents on a five-point scale ( $1=$ not direct at all; 5= highly direct) the extent to which an R\&D employee's evaluation results are linked with promotion and pay raises. We conducted a factor 
analysis (varimax-rotation) on these seven variables. This analysis resulted in one factor for which the eigen value exceeded one. This factor consisted of attitude or commitment, leadership, teamwork and potential capabilities. The Cronbach alpha for this construct was 0.690 .

\section{Control Variables}

Co-location was measured by a dummy variable: coded "1" if a R\&D subsidiary is located within a manufacturing facility, coded " 0 " if a R\&D subsidiary is located as an independent facility. $\boldsymbol{M} \boldsymbol{\&} \boldsymbol{A}$, was coded "1" if subsidiaries were established by M\&As, and coded were coded as " 0 " if subsidiaries are by greenfield development. Experience was measured by the number of years an R\&D subsidiary had been established in the United States. Sub Size was measured by using the number of R\&D personnel in the U.S. subsidiary. HQ Size was measured by the size of each parent company, using the total number of employees. Industry was coded " 0 " when firms are in pharmaceuticals, chemicals, plastics, ceramics, and metal products, and coded "1" when firms are in electrical appliances, automobiles and parts, transport equipment, and precision machines.

\section{REFERENCES}

[1] P. Aghion and J. Tirole, "Formal and real authority in organizations," J. Political Econ., vol. 105, pp. 1-29, 1997.

[2] A. Al-Harbi, M. Kamal, and A. S. Al-Dosary, "The process of nationalizing companies: a general model based on the Saudi Arabian experience," Int. J. Manag., vol. 18, no. 1, p. 59, 2001, Poole.

[3] T. J. Allen, Managing the Flow of Technology. Boston, MA: MIT Press, 1977.

[4] T. J. Allen and R. Katz, "The dual ladder: motivational solution or managerial delusion?," R\&D Manag., vol. 16, no. 2, pp. 185-197, 1986.

[5] T. J. Allen, M. L. Tushman, and D. Lee, "Modes of technology transfer as a function of position in the RD\&E spectrum," Acad. Manag. J., vol. 22, no. 4, pp. 699-708, 1979.

[6] P. Almeida, J. Song, and R. Grant, "Are firms superior to alliances and markets? An empirical test of cross-border knowledge building," Organization Sci., vol. 13, pp. 147-161, 2002.

[7] L. Argote, Organizational Learning: Creating, Retaining, and Transferring Knowledge. Boston, MA: Kluwer, 1999.

[8] L. Argote and D. Epple, "Learning curves in manufacturing," Science, vol. 247, no. 4945, pp. 920-924, 1990.

[9] L. Argote and P. Ingram, "Knowledge transfer: a basis for competitive advantage in firms," Organizational Behav. Hum. Decision Processes, vol. 82, no. 1, pp. 150-169, 2000.

[10] K. Asakawa, "Evolving headquarters-subsidiary dynamics in international R\&D: the case of Japanese multinationals," $R \& D$ Manag., vol. 31 , no. 1, pp. 1-14, 2001a.

[11] — "Organizational tension in international R\&D management: the case of Japanese firms," Res. Policy, vol. 30, no. 1, pp. 735-757, 2001b.

[12] C. A. Bartlett and S. Ghoshal, Managing Across Borders: The Transnational Solution. Boston, MA: Harvard Bus. Sch. Press, 1989.

[13] L. Benkard, "Learning and forgetting: the dynamics of aircraft production," Am. Econ. Rev., vol. 90, no. 4, pp. 1034-1054, 2000.

[14] P. Berger and T. Luckmann, The Social Construction of Reality: A Treatise in the Sociology of Knowledge. New York: Penguin Books, 1967.

[15] J. Birkinshaw, R. Nobel, and J. Ridderstrale, "Knowledge as a contingency variable: do the characteristics of knowledge predict organization structure?," Organization Sci., vol. 13, no. 3, pp. 274-289, 2002.

[16] H. Blumer, Symbolic Interactionism: Perspective and Method. Berkeley, CA: Univ. California Press, 1993.

[17] N. Boyacigiller, "The role of expatriates in the management of interdependence, complexity and risk in multinational corporations," J. Int. Bus. Studies, vol. 21, no. 3, pp. 357-381, 1990.

[18] S. Brelade and C. Harman, "Using human resources to put knowledge to work," Knowl. Manag. Rev., vol. 3, no. 1, p. 26, 2000.

[19] H. Bresman, J. Birkinshaw, and R. Nobel, "Knowledge transfer in international acquisitions," J. Int. Bus. Studies, vol. 30, no. 3, pp. 439-462, 1999.
[20] K. D. Brouthers, L. E. Brouthers, and S. Werner, "R\&D mode choices in central and Eastern Europe," J. Bus. Res., vol. 52, pp. 83-91, 2001.

[21] J. S. Brown and P. Duguid, "Organizational learning and communities-of-practice: toward a unified view of working, learning and innovation," Organization Sci., vol. 02, no. 01, pp. 40-57, 1991.

[22] R. A. Burgelman, "Fading memories: a process theory of strategic business exit in dynamic environments," Admin. Sci. Quart., vol. 39, pp. 24-56, 1994.

[23] D. T. Campbell and D. W. Fiske, "Convergent and discriminant validation by the multitrait-multimethod matrix," Psycholog. Bull., vol. 56, pp. 81-105, 1959.

[24] R. E. Caves, Multinational Enterprise and Economic Analysis. Cambridge, U.K: Cambridge Univ. Press, 1982.

[25] V. Chiesa, "Strategies for global R\&D," Res. Technol. Manag., vol. 39, no. 5, pp. 19-26, 1996.

[26] C. Christensen, "Molding the impossible: NYPRO/Vistakon disposable contact lens project," Harvard Business School Case (9-694-062) 1994.

[27] M. M. Crossan, H. W. Lane, and R. E. White, "An organizational learning framework: from intuition to institution," Acad. Manag. Rev., vol. 24, no. 3, pp. 522-537, 1999.

[28] J. L. Cummings and B. S. Teng, "Transferring R\&D knowledge: the key factors affecting knowledge transfer success," J. Eng. Technol. Manag., vol. 20, pp. 39-68, 2003.

[29] D. H. Dalton, M. G. Serapio, and P. G. Yoshida, Globalizing Indus trial Research and Development. Washington, DC: U. S. Dept. Commerce, Office Technol. Policy, 1999.

[30] E. L. Darr, L. Argote, and D. Epple, "The acquisition, transfer, and depreciation of knowledge in service organizations: productivity in franchises," Manag. Sci., vol. 41, no. 11, pp. 1750-1762, 1995.

[31] T. H. Davenport and L. Prusak, Working Knowledge: How Organizations Manage What They Know. Boston, MA: Harvard Bus. Sch. Press, 1998.

[32] T. H. Davenport, D. W. De Long, and M. C. Beers, "Successful knowledge management projects," Sloan Manag. Rev., vol. 39, no. 2, pp. 43-57, 1998.

[33] A. De Meyer, "Internationalizing R\&D improves a firm's technical learning," Res. Technol. Manag., pp. 42-50, Jul./Aug. 1993.

[34] I. Dierickx and K. Cool, "Asset stock accumulation and sustainability of competitive advantage," Manag. Sci., vol. 35, pp. 1504-1511, 1989.

[35] Y. L. Doz and G. Hamel, Alliance Advantage. Boston: Harvard Bus. Sch. Press, 1998.

[36] Y. L. Doz, J. Santos, and P. Williamson, From Global to Metanational: How Companies Win in the Knowledge Economy. Boston: Harvard Bus. Sch. Press, 2001.

[37] J. H. Dunning, "Reappraising the eclectic paradigm in an age of alliance capitalism," J. Int. Bus. Studies, vol. 26, no. 3, pp. 461-492, 1995.

[38] W. G. Egelhoff, Organizing the Multinational Enterprise-An Information-Processing Perspective. Cambridge, MA: Ballinger, 1988.

[39] R. Florida and M. Kenny, "The globalization of Japanese R\&D: the economic geography of Japanese R\&D investment in the United States," Econ. Geogr., vol. 70, no. 4, pp. 344-369, 1994.

[40] N. J. Foss and T. Pedersen, "The MNC as a knowledge structure: the roles of knowledge sources and organizational instruments in MNC knowledge management," DRUID Working Papers 03-09/DRUID Copenhagen Bus. School, Dept. Ind. Econ. Strategy/Alborg Univ., Dept. Bus. Studies, 2003.

[41] J. Galbraith, Organizational Design. Reading, MA: Addison-Wesley, 1977.

[42] D. A. Garvin and A. March, A Note on Knowledge Management, Harvard Business School Publishing Product\#: 398031, 1997.

[43] S. R. Gates and W. G. Egelhoff, "Centralization in headquarters subsidiary relationships," J. Int. Bus. Studies, pp. 71-93, 1986.

[44] P. Ghemawat, Strategy and the Business Landscape. Upper Saddle River, NJ: Prentice-Hall, 2001.

[45] P. Ghemawat, J. E. Ricart, and I. Costa, "The organizational tension between static and dynamic efficiency," Strategic Manag. J., vol. 14, pp. 59-73, 1993.

[46] S. Ghoshal and C. A. Bartlett, "Creation, adoption and diffusion of innovations by subsidiaries of multinational corporations," J. Int. Bus. Studies, vol. 19, no. 3, pp. 365-388, 1988.

[47] O. Grandstrand, L. Hakanson, and S. Sjolander, "Internationalization of R\&D: a survey of some recent research," Res. Policy, vol. 22, no. 5,6, pp. 413-431, 1993.

[48] R. M. Grant, "Toward a knowledge-based theory of the firm," Strategic Manag. J., vol. 17, pp. 109-122, 1996. 
[49] A. Griffin and J. R. Hauser, "Integrating R\&D and marketing: a review and analysis of the literature," J. Product Innovation Manag., vol. 13, pp. 191-215, 1996.

[50] A. K. Gupta and V. Govindarajan, "Business unit strategy, managerial characteristics and business unit effectiveness at strategy implementation," Acad. Manag. J., vol. 27, pp. 25-41, 1984.

[51] _ "Knowledge flows and the structure of control within multinational corporations," Acad. Manag. Rev., vol. 16, no. 4, pp. 768-792, 1991.

[52] _ - "Knowledge flows within MNCs," Strategic Manag. J., vol. 21, pp. 473-496, 2000.

[53] R. Habbel, G. Harter, and M. Stech, Knowledge Management: Knowledge-Critical Capital of Modern Organizations 1998 Booz Allen \& Hamilton Insights [Online]. Available: http://www.bah.com/viewpoints/insights/cmt_knowmanage_2.html

[54] L. Hakanson and R. Nobel, "Organizational characteristics and reverse technology transfer," Manag. Int. Rev., vol. 41, no. 4, 2001.

[55] M. T. Hansen and B. von Oetinger, "Introducing T-shaped Managers: Knowledge Management's Next Generation," HBR R0103G 2001.

[56] N. Hara, "Social construction of knowledge in professional communities of practice: Tales in courtrooms," Ph.D. dissertation, Indiana Univ., Bloomington, 2000.

[57] H. H. Harman, Modern Factor Analysis. Chicago, IL: Univ. Chicago Press, 1967.

[58] R. G. Havelock, Planning for Innovation Through Dissemination and Utilization of Social Research. Ann Arbor: Univ. Michigan, 1979.

[59] T. Hayashi, "Globalization and networking of R\&D activities: analysis centering around the cases of IBM Corp., Philips N. V. and NEC Co.," Economics Studies Rikkyou Univ. Tokyo, Japan, vol. 53, no. 1, pp. $1-27,1999$.

[60] G. Hedlund, "Autonomy of subsidiaries and formalization of headquarters-subsidiary relationships in Swedish MNCs," in The Management of Headquarters-Subsidiary Relations in Multinational Corporations, L. Otterbeck, Ed. Hampshire, U.K.: Gower, 1981, pp. 25-76.

[61] C. Helfat, "Know-how and asset complementarity and dynamic capability accumulation: the case of R\&D," Strategic Manag. J., vol. 18, no. 5, pp. 339-360, 1997

[62] Henderson and Clark, "Architectural innovation: the reconfiguration of existing product technologies and the failure of established firms," Admin. Sci. Quart., vol. 35, pp. 9-30, 1990.

[63] R. C. Hirschey and R. E. Caves, "Research and transfer of technology by multinational enterprises," Oxford Bull. Econ. Statist., vol. 43, pp. $115-131,1981$.

[64] S. H. Hymer, "The international operations of national firms," Ph.D. dissertation, Massachusetts Inst. Technol., Cambridge, 1960.

[65] M. Iansiti and K. B. Clark, "Integration and dynamic capability: evidence from product development in automobiles and mainframe computers," Ind. Corp. Change, vol. 3, pp. 557-605, 1994.

[66] A. C. Inkpen and S. C. Currall, "International joint venture trust: an empirical examination," in Cooperative Strategies: North American Perspectives, P. W. Beamish and J. P. Kiling, Eds. San Francisco, CA: The New Lexington Press, 1997, pp. 308-334.

[67] H. Itami, "Chukan-Soshiki no dilemma (prisoner's dilemma in quasimarkets)," Hitotsubashi Bus. Rev., vol. 39, no. 4, pp. 49-59, 1992.

[68] T. Iwasa and H. Odagiri, "Overseas R\&D, knowledge sourcing, and patenting: an empirical study of Japanese R\&D investment in the US," Res. Policy, 2004, to be published.

[69] S. Iwata, Globalization of R\&D. Tokyo, Japan: Bunshindo, 1994.

[70] _ _ "Overseas R\&D of Japanese companies," in Annals of Economic Studies. Kagawa, Japan: Kagawa Univ. Press, 1996.

[71] M. Jensen and W. Meckling, "Theory of the firm: managerial behavior, agency costs and ownership structure," J. Fin. Econ., vol. 3, pp. 305-360, 1976.

[72] JETRO, International Trade and Industry Report Tokyo, Japan, , 2003.

[73] T. Kagono, Soshiki-Ninshiki-Ron (Organizational Epistemology). Tokyo, Japan: Chikura-Shobo, 1990.

[74] T. Kagono, I. Nonaka, K. Sakakibara, and A. Okumura, Nichibei Kigyou no Keiei hikaku Transl.: A Comparative Study of Management in the U.S. and Japan. Tokyo, Japan: Nihon Keizai Shibun Sha, 1983.

[75] K. B. Kahn, "Interdepartmental integration: a definition with implications for product development performance," J. Product Innovation Manag., vol. 13, pp. 131-151, 1996.

[76] B. Kogut and U. Zander, "Knowledge of the firm and the evolutionary theory of the multinational corporation," J. Int. Bus. Studies, vol. 24, pp. 625-646, 1993.

[77] W. Kuemmerle, "Building effective R\&D capabilities abroad," Harvard Bus. Rev., pp. 61-71, Mar.-Apr. 1997.
[78] _ - "The drivers of foreign direct investment into research and development: an empirical investigation," J. Int. Bus. Studies, vol. 30, no. 1, pp. 1-24, 1999.

[79] S. Kurokawa, S. Chen, and R. Nash, "An empirical study on the relationships among knowledge, exchange of information and integration during new product development," in Strategic Management Society (SMS), Mini-Conference for Strategy Process Researchers, Consultants \& Practitioners, Storrs, CT, May 2003, pp. 25-2.

[80] D. M. Lamberton, "Introduction: 'Threatened Wreckage' or New Paradigm?," in The Economics of Communication and Information, D. M. Lamberton, Ed. Cheltham, U.K./Brookfield, WI: Edward Elgar, 1996.

[81] P. J. Lane and M. Lubatkin, "Relative absorptive capacity and interorganizational learning," Strategic Manag. J., vol. 19, pp. 461-477, 1998.

[82] P. J. Lane, J. E. Salk, and M. A. Lyles, "Absorptive capacity, learning, and performance in international joint venture," Strategic Manag. J., vol. 22, pp. 1139-1161, 2001.

[83] J. Lave and E. Wenger, Situated Learning: Legitimate Peripheral Participation. New York: Cambridge Univ. Press, 1991.

[84] D. Leonard-Barton, Wellsprings of Knowledge: Building and Sustaining the Sources of Innovation. Cambridge, MA: Harvard Bus. Sch. Press, 1995.

[85] D. A. Levinthal and J. G. March, "The myopia of learning," Strategic Manag. J., vol. 14, pp. 95-112, 1993.

[86] B. Levitt and J. G. March, "Organisational learning," Annu. Rev. Sociol., vol. 14, pp. 319-340, 1988.

[87] J. Liebeskind, A. Oliver, L. Zucker, and M. Brewer, "Social networks, learning, and flexibility: sourcing scientific knowledge in new biotechnology firms," Organization Sci., vol. 4, pp. 428-443, 1996.

[88] F. Machlup and U. Mansfield, Eds., The Study of Information: Interdisciplinary Messages. New York: Wiley, 1983.

[89] J. G. March, "Exploration and exploitation in organizational learning," Organization Sci., vol. 2, pp. 71-87, 1991.

[90] D. Marquis, "The anatomy of successful innovations," Innovation, pp. 35-48, Nov. 1969

[91] D. Minbaeva, T. Pedersen, I. Bjorkman, C. Fey, and H. Park, "MNC knowledge transfer, subsidiary absorptive capacity and HRM," J. Int. Bus., vol. 34, no. 6, pp. 586-599, 2003.

[92] R. K. Moenaert, W. E. Souder, A. D. Meyer, and D. Deschoolmeester, "R\&D-marketing integration mechanism, communication flows, and innovation success," J. Product Innovation Manag., vol. 11, pp. 31-45, 1994.

[93] D. Moitra and M. B. Krishnamoorthy, "Global innovation exchange," Res. Technol. Manag., pp. 32-38, Jul.-Aug. 2004.

[94] J. Nahapiet and S. Ghoshal, "Social capital, intellectual capital, and the organizational advantage," Acad. Manag. Rev., vol. 23, no. 2, pp. 242-266, 1998.

[95] V. K. Narayanan, Managing Technology and Innovation for Competitive Advantage. Englewood-Cliffs, NJ: Prentice-Hall Longman, 2001.

[96] K. Nishida, Fundamental Problems in Philosophy: The World of Action, the Dialectical. Tokyo, Japan: Sophia Univ. Press, 1970.

[97] J. Niosi, "The internationalization of industrial R\&D from technology transfer to the learning organization," Res. Policy, vol. 28, no. 2-3, pp. 107-117, 1999.

[98] R. Nobel and J. Birkinshaw, "Innovation in multinational corporations: control and communication patterns in international R\&D operations," Strategic Manag. J., vol. 19, pp. 479-496, 1998.

[99] N. Nohria and S. Ghoshal, "Differentiated fit and shared values: alternatives for managing headquarters-subsidiary relations," Strategic Manag. J., vol. 15, pp. 491-502, 1994.

[100] I. Nonaka and N. Konno, "The concept of "BA": building a foundation for knowledge creation," Calif. Manag. Rev., vol. 40, no. 3, pp. 40-54, 1998.

[101] I. Nonaka and R. Toyama, "Firm as a dialectic being: toward the dynamic theory of the firm," Ind. Corp. Change, vol. 11, pp. 995-1109, 2002.

[102] — , "The knowledge-creating theory revisited: knowledge creation as a synthesizing process," Knowl. Manag. Res. Practice, vol. 1, no. 1, pp. 2-10, 2003.

[103] NSF (National Science Foundation), Science \& Engineering Indicators 2004 National Science Board. Washington D.C., 2004.

[104] H. Odagiri and A. Goto, "The Japanese system of innovation: past, present and future," in National Innovation Systems, R. R. Nelson, Ed. New York: Oxford Univ. Press, 1993, pp. 76-114. 
[105] H. Odagiri and H. Yasuda, "The determinants of overseas R\&D by Japanese firms: an empirical study at the industry and company levels," Res. Policy, vol. 25, pp. 1059-1079, 1996.

[106] S. W. O'Donnell, "Compensation design as a tool for implementing foreign subsidiary strategy," Manag. Int. Rev., vol. 39, no. 2, pp. 149-165, 1999.

[107] B. D. Ottum and W. L. Moore, "The role of market information in new product success/failure," J. Product Innovation Manag., vol. 14, pp. 258-273, 1997.

[108] M. Papanastassiou and R. Pearce, "Technology sourcing and the strategic roles of manufacturing subsidiaries in the U.K.: local competences and global competitiveness," Manag. Int. Rev., vol. 37, pp. 5-26, 1997.

[109] R. Pearce and M. Papanastassiou, "R\&D networks and innovation: decentralized product development in multinational enterprises," $R \& D$ Manag., vol. 26, no. 4, pp. 315-334, 1996a.

[110] —-, The Technological Competitiveness of Japanese Multinationals: The European Dimension. Ann Arbor: Univ. Michigan Press, 1996b.

[111] J. D. Penner-Hahn, "Firm and environmental influences on mode and sequence of foreign research and development activities," Strategic Manag. J., vol. 19, pp. 149-168, 1998

[112] R. A. Ping, "Latent variable regression: a technique for estimating interaction and quadratic coefficients," Multivariate Behav. Res., vol. 31, no. 1, pp. 95-120, 1996.

[113] P. M. Podsakoff and D. W. Organ, "Self-reports in organizational research: problems and prospects," J. Manag., vol. 12, no. 4, pp. 531-544, 1986.

[114] W. Powell, W. Kenneth, W. Koput, and L. Smith-Doerr, "Interorganizational collaboration and the locus of innovation: networks of learning in biotechnology," Admin. Sci. Quart., vol. 41, pp. 116-145, 1996.

[115] P. M. Rosenzweig and N. Nohria, "Influences on human resource management practices in multinational corporations," J. Int. Bus. Studies, vol. 25 , no. 2 , pp. $229-252,1994$.

[116] A. Schutz, The Phenomenology of the Social World Transl.:G. Walsh and F. Lehnert. Evanston, IL: Northwestern Univ. Press, 1967.

[117] M. G. Serapio, Jr. and D. H. Dalton, "Globalization of industrial R\&D: an examination of foreign direct investments in $R \& D$ in the United States," Res. Policy, vol. 28, pp. 303-316, 1999.

[118] H. Sicotte and A. Langley, "Integration mechanisms and R\&D project performance," J. Eng. Technol. Manag., vol. 17, pp. 1-37, 2000.

[119] M. Subramaniam and N. Venkatraman, "Determinants of transnational new product development capability: testing the influence of transferring and deploying tacit overseas knowledge," Strategic Manag. J., vol. 22, pp. 359-378, 2001.

[120] G. Szulanski, "The process of knowledge transfer: a diachronic analysis of stickiness," Organizational Behav. Hum. Decision Processes, vol. 82, no. 1, pp. 9-27, 2000.

[121] M. V. Tatikonda and S. R. Rosenthal, "Technology novelty, project complexity and product development project execution success a deeper look at task uncertainty in product innovation," IEEE Trans. Eng. Manag., vol. 47, no. 1, pp. 74-87, Feb. 2000.

[122] D. J. Teece, "Profiting from technological innovation: implication for integration, collaboration, licensing and public policy," in The Competitive Challenge: Strategies for Industrial Innovation and Renewal, D. J. Teece, Ed. New York: Harper \& Row, 1987.

[123] D. J. Teece, G. Pisano, and A. Shuen, "Dynamic capabilities and strategic management," Strategic Manag. J., vol. 18, pp. 509-533, 1997.

[124] P. Thompson, "How much did the liberty shipbuilders learn? New evidence for an old case study," J. Political Econ., vol. 109, pp. 103-137, 2001.

[125] Toyo Keizai, Kaigai Shinshutsu Kigyou Souran (Overseas Activities of Japanese MNCs), Tokyo, Japan: Toyo Keizai, 1998.

[126] W. Tsai, "Knowledge transfer in intra-organizational networks: effects of network position and absorptive capacity on business unit innovation and performance," Acad. Manag. J., vol. 44, pp. 996-1004, 2001.

[127] W. Tsai and S. Ghoshal, "Social capital and value creation: the role of intrafirm networks," Acad. Manag. J., vol. 41, pp. 464-476, 1998.

[128] R. Vernon, "International investment and international trade in the product cycle," Quart. J. Econ., vol. 80, no. 2, pp. 190-207, 1966.

[129] von Hippel, The Source of Innovation. Oxford, U.K.: Oxford Univ. Press, 1988.

[130] B. Wernerfelt, "A resource-based view of the firm," Strategic Manag. J., vol. 5, pp. 171-180, 1984.
[131] K. E. Weick, Sensemaking in Organizations. Thousand Oaks, CA: Sage, 1995.

[132] M. K. Welge, "A comparison of managerial structures in German subsidiaries in France, India, and the United States," Manag. Int. Rev., vol. 21, no. 2, pp. 5-21, 1981.

[133] E. Westney, "Institutionalization theory and the MNE," in Organization Theory and the Multinational Corporation, S. Ghoshal and E. Westney, Eds. New York: St. Martin's Press, 1993, pp. 53-76.

[134] H. Yli-Renko, E. Autio, and J. H. Sapienza, "Social capital, knowledge acquisition, and knowledge exploitation in young technology based firms," Strategic Manag. J., vol. 22, pp. 587-613, 2001.

[135] H. Yoshihara, D. Methe, and S. Iwata, "Japanese R\&D subsidiaries in the US," R\&D Manag. (Kenkyu-Kaihatsu Manag.), vol. 11, no. 4, pp. 74-78, 2001.

[136] G. Zaltman and R. Duncan, Strategies for Planned Change. New York: Wiley, 1977.

[137] U. Zander and B. Kogut, "Knowledge and the speed of the transfer and imitation of organizational capabilities," Organization Sci., vol. 6, pp. 76-92, 1995

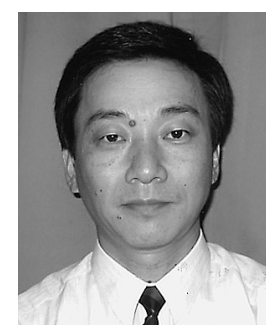

Satoshi Iwata received the M.B.A. degree from Kobe University, Kobe, Japan. He received the Ph.D. degree in business administration from Hokkaido University, Hokkaido, Japan.

$\mathrm{He}$ is a Research Associate Professor, Graduate School of Economics and Business Administration, Hokkaido University, Hokkaido, Japan. He has done extensive research and education with a particular focus on the multinational corporations at several universities. He has published several articles and books on management of multinational corporations and $R \& D$ activities. His current research interests are R\&D management innovation management and knowledge management in the field of global business.

Dr. Iwata is a member of Academy of Management and the Academy of International Business.

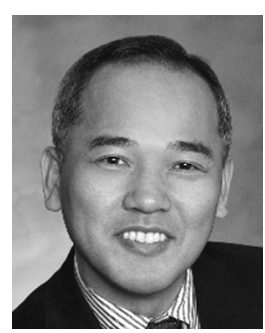

Sam Kurokawa received the B.A. (1980) and the MBA (1982) degrees from Kobe University, Kobe, Japan, in 1980 and 1982, respectively. He received the Ph.D. degree (1992) in management of technological innovation from the Sloan School of Management, Massachusetts Institute of Technology, Boston

$\mathrm{He}$ is an Assistant Professor of Management at the Bennett S. LeBow College of Business, Drexel University, Philadelphia, PA, since 2001. Before joining Drexel, he was a Research Associate Professor of Management of Technology at Vanderbilt University's School of Engineering, Nashville, TN, from 1996 to 2001. His current research interests include, interfirm strategic alliances, entrepreneurship, electronic commerce, supply chain management, international technology strategy, and quality management

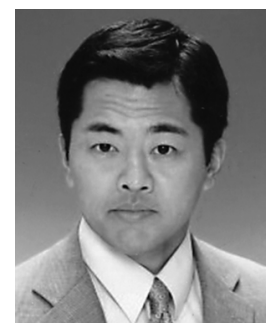

Kenzo Fujisue received the $\mathrm{Ph} . \mathrm{D}$. degree in industrial management from Tokyo Institute of Technology, Tokyo, Japan, in 1999, the M.S. degre in public administration from Harvard University, Cambridge, MA, in 1996, and the M.S. degree in management of technology from Massachusetts Institute of Technology, Cambridge, in 1995.

$\mathrm{He}$ is Visiting Associate Professor at Waseda University, Tokyo, Japan. He started working for the Ministry of International Trade and Industry in 1986 and he was promoted as Assistant Professor at the University of Tokyo, Tokyo, Japan, in April 1999. He became an Associate Professor in July 2000. His current research interests include, science policy, management of technology, and international $R \& D$ management. 